\title{
Inside the Virtuous Circle between Productivity, Profitability, Investment and Corporate Growth: An Anatomy of Chinese Industrialization
}

\author{
Xiaodan $\mathrm{Yu}^{\mathrm{a}, \mathrm{b}}$, Giovanni Dosi ${ }^{\mathrm{a}, \mathrm{b}, *}$, Marco Grazzi ${ }^{\mathrm{c}}$, Jiasu Lei $^{\mathrm{d}}$ \\ ${ }^{a}$ Institute of Economics, Scuola Superiore Sant'Anna, Piazza Martiri della Libertà 33, 56127 Pisa, Italy \\ ${ }^{b}$ IBIMET-CNR, via Giovanni Caproni 8, 50145 Firenze, Italy \\ ${ }^{c}$ Department of Economics, University of Bologna, Piazza Scaravilli 2, 40126 Bologna, Italy \\ ${ }^{d}$ Department of Innovation, Entrepreneurship and Strategy, School of Economics and Management, Tsinghua \\ University, Beijing 100084, China
}

\begin{abstract}
This work explores the dynamics of the 'virtuous circle' driving the impressive Chinese catching-up and growth by investigating the micro relationships linking productivity, profitability, investment and growth, based on China's manufacturing firm-level dataset over the period 1998 - 2007. Interestingly and somewhat puzzlingly, we find that productivity variations, rather than relative levels, are the prevalent productivity-related determinant of firm growth. Moreover, the direct relation between profitability and firm growth is much weaker and its contribution to the explanation of the different rates of firm growth is almost negligible. The only visible profitability-growth relationship is mediated via investment. Firm's contemporaneous and lagged profitabilities display positive and significant effect on the probability to report an investment spike, and, in turn, investment activities are related to higher firm growth.
\end{abstract}

Keywords: Productivity, learning, profitability, virtuous circle, catching-up, Chinese industry JEL: D22, L10, L20, L60, O30

\footnotetext{
*Corresponding author. Tel.: +39 050883343; fax: +39 050883344.

Email addresses: x.yu@santannapisa.it (Xiaodan Yu), giovanni.dosi@santannapisa.it (Giovanni Dosi), marco.grazzi@unibo.it (Marco Grazzi), leijs@sem.tsinghua.edu.cn (Jiasu Lei)
} 


\section{Introduction}

The last three decades witnessed an impressive growth of the Chinese economy. Indeed, China undertook a deep and fast great transformation - borrowing Karl Polanyi (1944) expression - leading from a traditional mostly rural economy to an economy driven by industrial activities. China's real per capita GDP has grown from only one-fortieth of the U.S. level and one-tenth the Brazilian level in 1978 to almost one-fifth the U.S. level and at the same level as Brazil by 2012 (Zhu, 2012). What has driven such a striking performance?

Grounded on a growth accounting decomposition framework, Zhu (2012) concludes that China's rapid growth over the last three decades has been mainly driven by total factor productivity (TFP) growth rather than by capital investment. ${ }^{1}$ However, in our view, decomposition effects are likely to only scratch the surface of a phenomenon characterized by widespread complementarities, processes of circular causation and cumulative dynamics (Myrdal, 1957):

All [...] frustrating effects of poverty, operating through other media than those analyzed by traditional economic theory, are interlocked in circular causation, the one with the others and all with the biases I referred to in the working of migration, capital movements and trade. The opposite effects of rising economic levels in the centres of expansion are in a similar fashion also inter-connected in a circular causation, continuously sustaining further expansion in a cumulative fashion. [...] if the expansionary momentum is strong enough to overcome the backwash effects from the older centres, new centres of self-sustained economic expansion [develop] (Myrdal, 1957, pp.30-31).

In a circular causation framework increasing returns are widespread (Myrdal, 1957; Kaldor, 1972; Cimoli, Dosi, and Stiglitz, 2009). In fact, the patterns of accumulation of knowledge and capabilities, at the levels of individuals, organizations and countries are at the core of increasing returns. The 'unbound Prometheus' systematically accumulating and improving technological and organizational knowledge is a crucial deus ex machina of the early industrialization of almost three centuries ago, and as well as of subsequent episodes of development (Landes, 1969; Freeman and Soete, 1997). The rapid economic catch-up and industrialization in China is no exception, in that it entails more of learning and "creative restructuring" of domestic firms rather than sheer "creative

\footnotetext{
${ }^{1}$ In such estimates, the growth contributions made by human capital accumulation and increase in labour participation, the other two sources of growth in growth accounting decomposition, are positive but modest (Zhu, 2012).
} 
destruction" and even less so a multinational corporation-led drive (Yu et al., 2015). The rapid catching-up since 1978 is characterized by mobilizing the capabilities in part accumulated in the pre-liberalized stage and the high rates of investment after launching the economic reform which incorporates both the employment of modern machineries, organizational restructuring and learning. Chinese industrialization has certainly involved catching-up of all sectors by means of big and coordinated investment and capital accumulation, in the spirit of what suggested by the founding fathers of development economics (Nurkse (1953), Gerschenkron (1962), Rosenstein-Rodan (1943, 1961), Hirschman (1958), Prebisch (1949)). However, more importantly, the catching-up has been associated with learning effects well beyond the sheer accumulation of capital, involving the improvement of technological and organizational capabilities and the more efficient use of both capital and labour (Cimoli, Dosi, and Stiglitz, 2009; Lee, 2013). This is not at all unique to China: see Lee (2013) for the interpretation of catching-up in Korea - basically a story of capability accumulation at the firm-level, involving also a considerable degree of State activism.

In this work, we explore the microeconomic evidence on China's industrialization, the "virtuous circle" linking highly heterogeneous firm-level productivities, profitabilities, investments and corporate growth, both driven by and leading to firm-level technological and organizational learning and capability accumulation. Such virtuous circle is sketched in Figure 1.

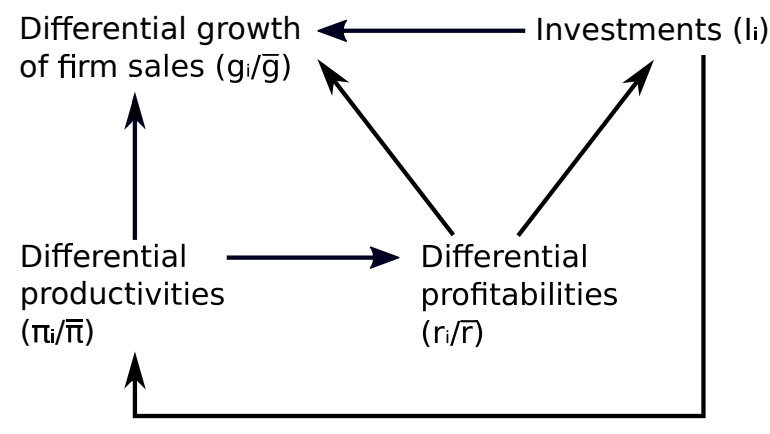

Figure 1: The virtuous circle.

Note that the accumulation of production knowledge and process innovation underlying the impressive Chinese catching-up in productivity is only one, albeit crucial element of the whole virtuous circle driving the great transformation. Another major one is the influence exerted by the huge productivity differentials across firms upon corporate growth (and mortality) - i.e., the selection effect. In particular here, we focus on the effects of productivities, both in levels and 
growth rates, upon the patterns of firm growth in Chinese manufacturing over the 1998-2007 period. Moreover, we consider the possibility that effect of productivity upon firm growth is not exerted directly, but is mediated via profitability and investment in tangible assets. Together, we also investigate the role played by different governance and ownership structures.

We find that relative productivity growth rather than relative levels are the prevalent productivityrelated determinants of firm growth. Conversely, the direct relation between profitability and firm growth is much weaker and its contribution to the explanation of the different rates of firm growth is almost negligible. Rather, the only detectable profitability-growth relationship appears to be mediated via investment. Contemporaneous and lagged profitabilities display positive and significant effect on the probability of displaying a large investment episode. We also find that such effect varies significantly across firm's ownership types: Chinese domestic private-owned enterprises (POEs) appear to be more financially constrained than State-owned enterprises (SOEs). In turn, firms' investment activities are related to better performances, and such effect is more significant for State-owned enterprises than other types of firms.

In section 2, we offer a telegraphic outline of our theoretical and empirical points of departures. Section 3 describes data and variables. Section 4 discusses the relationship between relative productivities and corporate growth. Section 5 considers the influence of profitabilities upon investments and section 6 shows the impact of the latter on firm growth. Section 7 concludes.

\section{Theoretical and empirical roots}

\subsection{Vicious and virtuous circles}

Myrdal (1957) suggests that the principle of interlocking, circular inter-dependence within a process of cumulative causation - nowadays we would say dynamic increasing returns - should be the paradigm when studying the development process. The circular causation process can work either in a "vicious" or a "virtuous" fashion, which can be influenced by the exogenous changes out

of the local system. Myrdal (1957) gives a simple example of the "virtuous circle" (often discussing "vicious circles"), addressing its spatially local dimension:

The cumulative process, $[\ldots]$, also works if the initial change is for the better. The decision to locate an industry in a particular community, for instance, gives a spur to 
its general development. Opportunities of employment and higher incomes are provided for those unemployed before or employed in a less remunerative way. Local business can flourish as the demand for their products and services increases. Labour, capital and enterprise are attracted from outside to exploit the expanding opportunities. The establishment of a new business or the enlargement of an old one widens the market for others, as does generally the increase of incomes and demand, [...] and the expansion process creates external economies favourable for sustaining its continuation. (Myrdal, 1957, pp.25)

Note that in such a circular causation framework, there are conflicting forces driving either toward divergence or convergence among regions or countries. Market forces normally tend to increase, rather than to decrease, the inequalities among regions/countries. Conversely, the "expansionary momentum", the development remedies - coordinated investmentS on a large scale of complementary industries - as the founding figures of development economics suggested involve "[an] industrializaton processes [which begin] only if the industrializaton movement can proceed along a broad front, starting simultaneously along many lines of economic activities. This is partly the existence of complementarity of indivisibilities in economic processes. [...] Fruits of industrial progress in certain lines are received as external economies by other branches of industry whose progress in turn accords benefits to the former" (Gerschenkron, 1962).

In all that, increasing returns in manufacturing play a special role. As Kaldor (1972) argues, first, plant cost per unit of output decrease with size in any integrated process of operation; second, scale fosters division of labour and together automation of production; third, learning-by-doing effects, "the annual gain of productivity due to 'embodied technical progress' will tend to be all the greater the larger the number of plants constructed per year." (Kaldor, 1972, pp. 1243)

Moreover, in line with, but well beyond the large-scale coordinated investment stimulus and the sheer accumulation of capital, the great transformation - industrialization - involves processes able to systematically learn how to implement and eventually generate new ways of producing and new products under conditions of dynamic increasing returns (Cimoli, Dosi, and Stiglitz, 2009). Such a 'great transformation' entails a major process of accumulation of knowledge and capabilities, both at the levels of individuals and organizations. Certainly, part of such capabilities builds on education and formally acquired skills. However, at least important, capabilities have to do with the problem- 
solving knowledge embodied in organizations - concerning e.g. production technologies, marketing, labour relations as well as 'dynamic capabilities' of search and learning. (pp 2.)

Together, the dynamics of industrialization rests upon major structural transformations which entail a changing importance of different branches of economic activity as generators of both technological and organizational innovators. In each epoch there appears to be technologies whose domains of application are so wide and their role so crucial that the pattern of technical change of each country depends to a large extent on the national capabilities in mastering production/imitation/innovation in such crucial knowledge areas (e.g. in the past, mechanical engineering, electricity and electrical devices, and nowadays also information technologies). Moreover, the linkages among production activities often embody structured hierarchies whereby the most dynamic technological paradigms play a fundamental role as sources of technological skills, problem-solving opportunities, and productivity improvements. Thus, these core technologies shape the overall absolute advantages/disadvantages of each country. Moreover, the patterns of technical change of each country in these core technologies are complementary to the technological capabilities in other activities.

This basic story finds an increasing support by learning-/capability - centered reconstructions of the development processes: see Freeman (1987); Lee and Kim (2009) and Cimoli, Dosi, and Stiglitz (2009) among many others cited there.

The analysis of the microeconomics of such processes, however, is still far lagging behind. The work which follows is meant also as a contribution to filling such a gap.

\subsection{The microeconomics}

Consider first the micro relation between productivity and growth.

There are two channels through which productivity may fuel firm growth. A first, direct, channel is that whereby more efficient firms gain market shares and grow more than competitors by setting lower prices. If competitiveness is inversely related to prices, and in turn prices are inversely related to productivity, the law of motion of a replicator-type dynamic of shares of firms in any one industry is such that firms with above-average productivity should display above-average growth and increase their market shares, and vice versa for less productive firms. ${ }^{2} \mathrm{~A}$ second, indirect,

\footnotetext{
${ }^{2}$ In this first approximation we do not mean to address the (hard) disentangling between physical productivity, and value added at constant prices, and neither the issue which are the proper indexes to deflate output and value
} 
channel is that whereby more efficient firms operating in a competitive, price-taking market ought to enjoy higher profits and hence would invest more, especially in presence of imperfect capital markets, and consequently gain market shares at the expenses of competitors (Nelson and Winter, 1982; Bottazzi et al., 2001).

On the empirical side our point of departure is the impressive heterogeneity that one observes across firms in all measures of efficiency irrespectively of the levels of disaggregation, the time window of observation and the country considered. This applies to developed countries (see, among others, Bartelsman and Doms, 2000; Dosi, 2007; Syverson, 2011), and even more so to emerging economies: we document and analyze the phenomenon in detail in the case of China in Yu et al. (2015). It is plausible to expect that such persistent heterogeneity ought to have some systematic, direct or indirect, effect upon corporate performances and in particular corporate growth.

The evidence on the ways higher relative efficiencies directly translates into higher firm growth is somewhat puzzling. Bottazzi et al. (2010) report that productivity levels of the firms have surprisingly low power in explaining the variance of firms' growth rates. On the contrary, the latter are mostly accounted for by time invariant unobserved variables ("fixed effects"), ultimately capturing also idiosyncratic degrees of "strategic freedom" of individual firms. ${ }^{3}$ Another procedure, aiming at extracting out of unobserved fixed effects the part which correlates with within-firm average productivities, is proposed in Dosi et al. (2015). This is the analytical route that we shall also follow here. Dosi et al. (2015) show a higher explanatory power (20\%) of relative productivities for differential firm growth as compared to 5\% explanatory power in Bottazzi et al. (2010).

Come as it may, there are also indirect channels through which higher efficiency might contribute to firm growth. One of them is mediated via profitabilities. The effect of selection via profitabilities (and differential investment rates) has been much less studied. Among the few works, Coad (2007) does not find any robust association between profitabilities and subsequent growth.

added (cf. Foster et al., 2008).

${ }^{3}$ Behind such a finding there are also technical reasons: it tends to happen when the explanatory variable, productivity levels in this case, is rather invariant over time and is collinear with the firm fixed effect (see Section 2.1 in Arellano, 2003). Hence resorting to plain fixed effects models washes away the contribution of the average efficiency of a firm over the observed period, which result in a systematic underestimation of the "true" contribution of the relative efficiency variable to relative firm growth. 
If higher efficiency translates into higher profitability and, other things being equal, into higher cash-flows, then under massive capital market imperfections as it is the rule everywhere, more internal financial resources untie financial constraints and hence allow the acquisition of more new-vintage investments, which might foster firm growth. Note that if investments are a crucial mediating variable, their analysis is particularly tricky, due to the lumpy nature of investment activities at firm-level (cf. the seminal Doms and Dunne (1998) and the following stream of studies): years of inactivity or repair and maintenance are followed by one or several years of heavy investment, displaying some but limited synchronization with the industry business cycle (cf. Carpenter et al. (1998); Fagiolo and Luzzi (2006); Brown et al. (2009)).

Rather intuitively, large investment projects require correspondingly conspicuous financial resources. If those available internally are insufficient, the firm will have to rely on external finance to realize the project and this might lead to two consequences. First, the acquisition of new equipment and capital stock will be constrained, that is, the firm's desired level of investment will be curbed because of limited access to external finance (cf. Fazzari et al., 1988; Schiantarelli, 1996; Audretsch and Elston, 2002; Whited, 2006). Second, to the extent that investment is associated to firm growth, the existence of financial constraints will preclude the possibility to exploit opportunities for growth even when they notionally exist. Thus, limited access to external finance will constraint firm growth (see, among the others Oliveira and Fortunato, 2006; Whited, 2006). Notice in this respect that "imperfections" of the financial system tend to be more pronounced in an emerging economies such as China (see among the others Cull and Xu, 2003; Allen et al., 2012; Chen and Guariglia, 2013). In the following we shall investigate the relevance of financial constraints (as proxied by limited internal financing) among Chinese firms, conditional on the different ownership structures. Indeed, incumbent evidence shows that they matter (Guariglia et al., 2011) especially in terms of constraints for the growth to private firms.

In accordance with most of the literature on capital adjustment patterns, we study both the effects of firm-level characteristics on the likelihood to display an investment spike as well the impact of spikes on firm performance resorting to a framework which is standard in the literature on capital adjustment, see among the others, Sakellaris (2004), Licandro et al. (2003), Nilsen et al. (2009), Grazzi et al. (forthcoming) and Asphjell et al. (2014). In particular, following an investment spike one expects to observe a productivity increase, which in turn translates into market share 
gains, thus sales and employment growth. The empirical literature on the subject (Power, 1998; Huggett and Ospina, 2001; Sakellaris, 2004; Shima et al., 2010) has only partially confirmed these theoretical conjectures. While the effect of investment spikes on productivity growth seems often to be negative in the short run (probably due to the inefficiencies associated with production reorganization), studies evaluating long-run impacts often fail to detect a positive relation between investment lumps and productivity growth. The evidences on investment activity of Chinese firms is very limited. ${ }^{4}$ What we know (see Lee (2016)), is that i) private enterprises have a higher propensity to invest than firms of other ownership types, and such investment patterns may be behind the higher labour productivity growth as compared to foreign-invested and State-owned enterprises; ii) in the most recent period (2005-09) the effect of investment upon productivity is positively scaled-biased among private firms, and also in State-owned ones. By contrast, foreigninvested enterprises displayed only a modest investment activity and a relatively stagnant labour productivity.

Of course below we shall also focus again on the investment-productivity nexus as it is a crucial element of the virtuous circle discussed above.

\section{Data and Variables}

This work draws upon firm level data collected by the Chinese National Bureau of Statistics (NBS). The database includes all industrial firms with sales above 5 million RMB covering period 1998-2007 and has already been employed in other empirical investigations, among others, Hu et al. (2005); Fu and Gong (2011); Yu et al. (2015). ${ }^{5}$ Each firm is assigned to a sector according to the 4-digit Chinese Industry Classification (CIC) system that closely matches the Standard Industrial

\footnotetext{
${ }^{4}$ Chen et al. (2011), based on a Tobin's Q framework, show that the sensitivity of investment expenditures to investment opportunity is significantly weaker for SOEs than for non-SOEs, suggesting less investment efficiency in SOEs. Dollar and Wei (2007), measuring investment efficiency in terms of return to capital, shows that SOEs have significantly lower returns to capital than domestic private or foreign-invested firms.

${ }^{5}$ Industry is defined to include mining, manufacturing and public utilities, according to National Bureau of Statistics of China (NBSC). Five million RMB is approximately $\$$ US 600,000. The total output and value added are not available in 2004 , thus, we do not use data for that year.
} 
Classification (SIC) employed by the U.S. Bureau of Census. ${ }^{6}$ Out of the comprehensive set of all firms, we focus on manufacturing firms only. We then apply a few cleaning procedures to the resulting set of data in order to eliminate visible recording errors (see Table A.1). We will refer to the final version of the database as "China Micro Manufacturing" (CMM). ${ }^{7}$

We are interested in corporate performances as revealed by several major dimensions, namely, productivity, profitability, investment rate and firm growth. Productivity $\Pi_{i, t}$ is the ratio of value added, at constant prices, over the number of employees, $\Pi_{i, t}=\frac{V A_{i, t}}{N_{i, t}}$, where $V A_{i, t}$ is real value added, ${ }^{8} N_{i, t}$ is the number of employees, of firm $i$ at year $t .{ }^{9}$ Labour costs $C O L_{i, t}$ are defined as the sum of total wages and social security contributions. Our proxy for profitability are the gross profit margins, that is the ratio between gross profits and output: $P_{i, t}=\frac{V A_{i, t}-C O L_{i, t}}{\text { Output }{ }_{i, t}}{ }^{10}$ Firm growth is measured as the log difference of (constant price) sales in two consecutive years:

\footnotetext{
${ }^{6}$ In 2003, the classification system was revised. Some sectors were further disaggregated, while others were merged together. To make the industry codes comparable over time, we adopted the harmonized classification proposed in Brandt et al. (2012).

${ }^{7}$ We applied the following cleaning procedure. We dropped firms with missing, zero or negative output, valueadded, sales, original value of fixed assets, cost of labour; and also firms with a number of employees less than 8 , since below that threshold they operate under another legal system (Brandt et al., 2012). Finally, note that NBSC modified the industrial classification after 2002. In this paper we employ the industrial classification in use before 2003. Since sector "recycling of waste and scrap" was emerged during the observation period, we do not consider it here.

${ }^{8}$ According to the definition of NBSC, value added = gross output - intermediate input + value added tax. Gross industrial output value: "the total volume of final industrial products produced and industrial services provided during a given period. It reflects the total achievements and overall scale of industrial production during a given period" (China Statistical Yearbook, 2007).

${ }^{9}$ Value-added is deflated by four-digit sectoral output deflators, from Brandt et al. (2012).

${ }^{10}$ We use output as the denominator instead of sales in order to be consistent with the NBSC methodology of computing value added, which is the difference between output and intermediate inputs. Also notice that the two variables, output and sales, are highly correlated, with a 0.99 correlation coefficient. We have chosen gross profit margins as a measure of profitability, first, because it is less subject to accounting manipulation, a practice quite widespread in China (Cai and Liu, 2009) as elsewhere. Second, it broadly corresponds to the MBITDA (margins before interest, tax, depreciation and amortization) quite used in the management literature. Third, it is a rather close proxy for cash flows, as such a variable which is likely to influence investments. Prompted by a referee, however, we tried other (net) measures of profitability. The results of the exercises shown is Section 5, however do not qualitatively change (the elaborations are available on request).
} 
$G_{i, t}=\log$ Sales $_{i, t}-\log$ Sales $_{i, t-1}$. Firm's investment rate at time $t$ is defined as the ratio of investment at time $t$ and capital stock at time $t-1$. Investment is not directly reported in the data. Thus, we compute investment at time $t$ as the difference of firm's fixed assets between time $t$ and $t-1 .{ }^{11}$ The series of "real" capital stock are then computed following the perpetual inventory method, with the rate of depreciation 9\% (as in Brandt et al., 2012). Table A.2 reports statistics of the mean values of the variables of interest.

We identify seven categories of firms according to their ownership and governance structures. They are State-owned enterprises (SOEs); collective-owned enterprises (COEs), Hong Kong, Macao and Taiwan-invested enterprises (HMTs); foreign-invested enterprises (FIEs), including foreign MNCs (FMNC) and joint ventures (JV) with a foreign share above 25\%; shareholding enterprises (SHEs), that is State-private Chinese joint ventures; private-owned enterprises (POEs); and other domestic enterprises (ODEs). As reported in Table A.3, the original 23 registration categories have been aggregated in line with Jefferson et al. (2003).

\section{Relative productivities and firm growth}

Let us start by looking at the relationship between firm productivities and growth rates by means of a simple bivariate kernel regression. Figure 2 reports the productivity-growth relationship for three rather typical 3-digit sectors. The plots highlight the existence of a positive but mild relation between contemporaneous (relative) productivities and relative growth rates, well in line to what shown in Bottazzi et al. (2010).

In order to allow for a richer structure in the productivity-growth relationship, we employ a distributed lag $(\log )$ linear model with fixed effect (Bottazzi et al., 2010; Dosi et al., 2015). ${ }^{12}$ Based on sequential rejection of the statistical significance of longer lags structure, we choose as our baseline equation a model with one lag for productivity:

$$
g_{i, t}=\alpha+\beta_{0} \pi_{i, t}+\beta_{1} \pi_{i, t-1}+\gamma_{1} S I Z E_{i, t-1}+\gamma_{2} A G E_{i, t-1}+b_{t}+u_{i}+\epsilon_{i, t}
$$

\footnotetext{
${ }^{11}$ According to NBSC, fixed assets include equipment and buildings.

${ }^{12}$ Lagged values are required for the strict exogeneity of the error term imposed for consistency of standard panel estimators.
} 

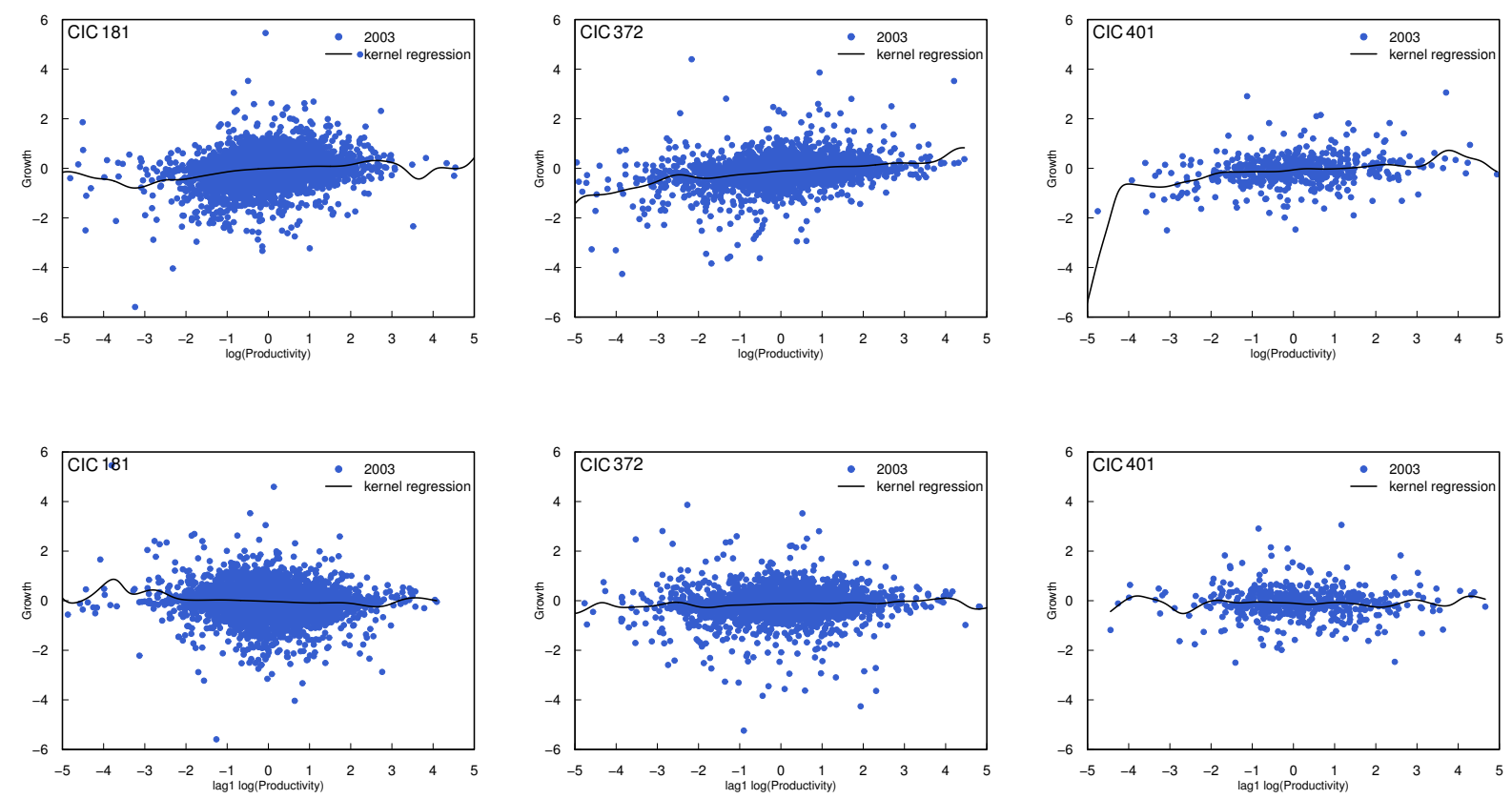

Figure 2: Productivity - Growth relationship in selected 3-digit sectors (textile clothing, automobiles and communication equipment) - kernel regression of 2003. Source: our elaboration on CMM. Note: the first row shows current relationship and the second row shows lagged relationship.

where $g_{i, t}$ denotes the growth rate of firm $i$ in terms of log-differences of sales between two consecutive years, $\pi_{i, t}$ is the (log) labour productivity, $b_{t}$ is a time dummy, $u_{i}$ is a firm-specific time invariant unobserved effect, and $\epsilon_{i, t}$ is the error term. ${ }^{13}$ We also include firm size (proxied by number of employees) and age as additional controls $\left(S I Z E_{i, t-1}\right.$ and $\left.A G E_{i, t-1}\right) .{ }^{14}$

Equation 1 is estimated for each of the available 3 digit sectors and the distribution of parameters $\beta_{0}, \beta_{1}$ and $\beta_{0}+\beta_{1}$ is shown in Figure $3 .{ }^{15}$ The absolute values of the two coefficients are quite stable across sectors with median 0.2. Note also that $\beta_{0}$ and $\beta_{1}$ are of opposite sign and of similar magnitude. This was shown, on a different set of data, also in Dosi et al. (2015) and can be interpreted as revealing a sort of regression to the mean.

\footnotetext{
${ }^{13}$ Note that the presence of time dummies is equivalent to consider the variables in deviation from their crosssectional average, so that what matters is only the relative efficiency of firms in the industry.

${ }^{14}$ We thank one of the referee for the suggesting to include these further controls.

${ }^{15}$ The "violin" shaped plot reports a box plot and a kernel density distribution to each side of the box plot. The box plot reports the median values and interquartile ranges. The table with the point estimates for all 3 digit sectors is available upon request.
} 


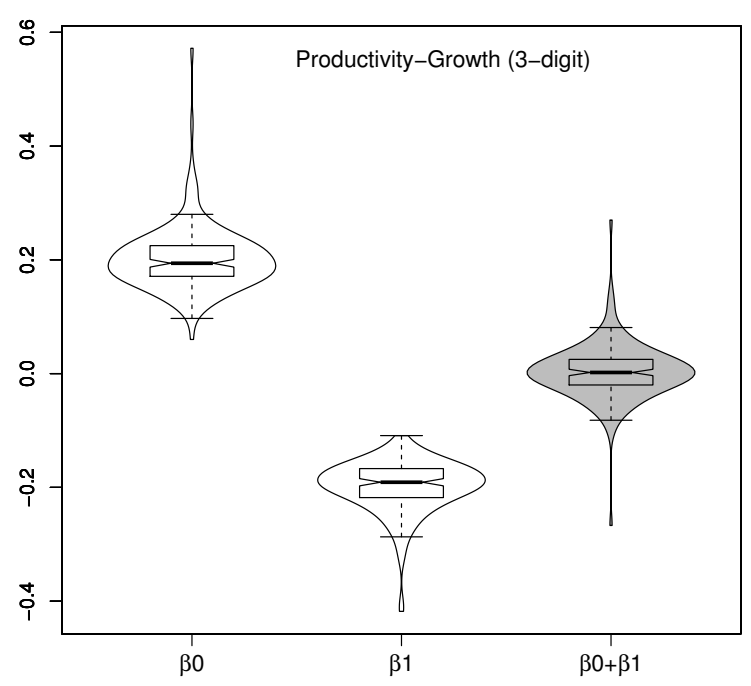

Figure 3: Productivity - Growth relationship at 3-digit sectoral level. Distribution of parameters $\beta_{0}, \beta_{1}$ and $\beta_{0}+\beta_{1}$ of the baseline model, based on 3 digit sectors estimates.

Despite the statistical significance, the coefficient estimates are not very informative on the extent to which firms are "selected", that is, how their market shares vary according to their relative productivities. To assess the strength of competitive selection, one needs to resort to a coefficient of determination to assess the proportion of the variance of firm growth explained by current and past relative productivities. Bottazzi et al. (2010) report in the case of Italy and France that the current relative productivity appears to "explain" roughly between $3 \%$ and $5 \%$ of the overall variance in growth, while the contribution of firm's unobserved idiosyncratic characteristics is much larger. In order to tell apart the effects due to average productivity levels from "genuine" firm fixed-effects we disentangle within the unobserved effect $u_{i}$, the part which correlates with productivity from the part which does not (see also Dosi et al., 2015). It is then possible to re-estimate Equation (1) through a Correlated Random Effects model:

$$
g_{i, t}=\alpha+\beta_{0} \pi_{i, t}+\beta_{1} \pi_{i, t-1}+\beta_{0 a} \bar{\pi}_{i}+\beta_{1 a} \bar{\pi}_{i,-1}+\gamma_{1} S I Z E_{i, t-1}+\gamma_{2} A G E_{i, t-1}+b_{t}+\mu_{i}+\epsilon_{i, t}
$$

where $\bar{\pi}_{i}$ and $\bar{\pi}_{i,-1}$ are the within-firm time series averages of the (log) productivity up to time $t$ and time $t-1$, respectively, while $\mu_{i}$ is the new unobserved firm-specific heterogeneity term, 
uncorrelated with the productivity regressors after controlling for their averages. The advantage with respect to Equation (1) is that we are explicitly taking into account the contribution to sales growth also of productivity averages over time. The random effects estimates from Equation (2) hardly change the value of the coefficients $\beta_{0}$ and $\beta_{1} \cdot{ }^{16}$

However, our main interest lies in a measure of the fraction of total variance of firm growth explained by productivity terms, and we compute it as follows

$$
S^{2}=\frac{\operatorname{Var}\left(\beta_{0} \pi_{i, t}+\beta_{1} \pi_{i, t-1}+\beta_{0 a} \bar{\pi}_{i}+\beta_{1 a} \bar{\pi}_{i,-1}\right)}{\operatorname{Var}\left(g_{i, t}\right)} .
$$

while the conventional coefficient of determination of the overall fit of the model

$$
R^{2}=\frac{\operatorname{Var}\left(\beta_{0} \pi_{i, t}+\beta_{1} \pi_{i, t-1}+\beta_{0 a} \bar{\pi}_{i}+\beta_{1 a} \bar{\pi}_{i,-1}\right)+\operatorname{Var}\left(\gamma_{1} S I Z E_{i, t-1}+\gamma_{2} A G E_{i, t-1}+\mu_{i}\right)}{\operatorname{Var}\left(g_{i, t}\right)}
$$

takes into account the contribution of the heterogeneity term $\mu_{i}$ and other control variables, so that the difference between $R^{2}$ and $S^{2}$ delivers a measure of the variance explained by time invariant firm's unobserved effects and additional control variables.

Figure 4 reports the distributions of the values of $R^{2}$ and $S^{2}$ together with $S_{\Delta}^{2}$ and $S_{a}^{2}$ (i.e., the decomposition of $S^{2}: S_{\Delta}^{2}$ represents the part of $S^{2}$ due to productivity variation; $S_{a}^{2}$ represents the part of $S^{2}$ due to average productivity level) based on 3-digit sectors estimates. Our model with levels and averages of productivity plus firm-level heterogeneity is able to account for around $47 \%-59 \%$ of the variance in sales growth. The median of the $R^{2} \mathrm{~s}$ is $52.81 \%$. The median value of $S^{2}$, capturing only the contribution of the productivity regressors (both levels and averages), is $14.36 \%$. That is, productivity variables appear to account for around one sixth of the variance in firms' growth rates. The explanatory power of productivity variables, hint at an important even if not overwhelming role of efficiency-driven competitive selection. ${ }^{17}$

The last four columns of Table 1 also show, for sake of robustness, the corresponding measures based on total factor productivity (TFP) at 3- and 4- digit respectively, (however, see the caveats

\footnotetext{
${ }^{16}$ Results are available upon requests.

${ }^{17}$ To provide robustness check, this property also holds at more disaggregated level, 4-digit sectoral level. Mean and median statistics are reported in Table 1.
} 


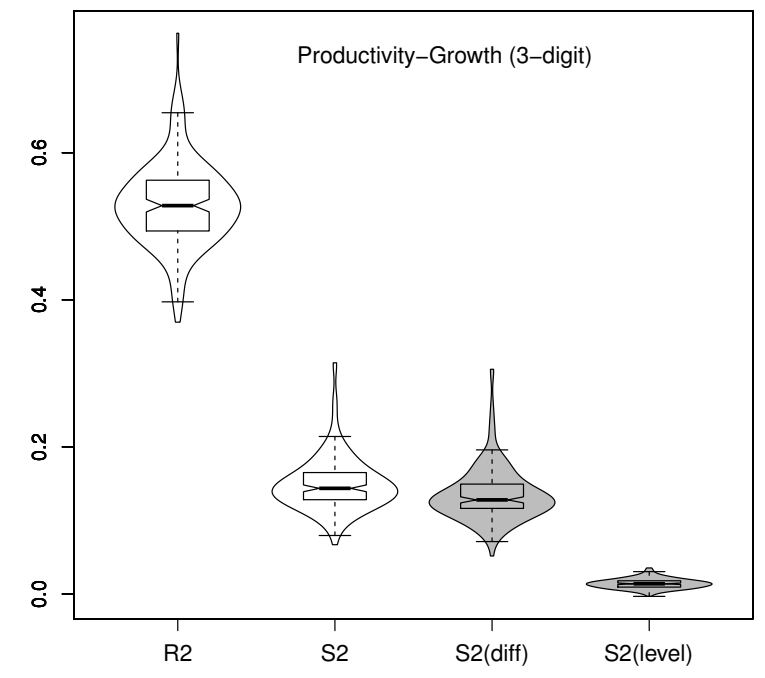

Figure 4: Productivity - Growth relationship at 3-digit sectoral level. Distributions of $R^{2}, S^{2}, S_{\Delta}^{2}$ and $S_{a}^{2}$, based on 3 digit sectors estimates. Note: the shaded violins refer to $S_{\Delta}^{2}$ and $S_{a}^{2}$.

\begin{tabular}{|c|c|c|c|c|c|c|c|c|}
\hline & \multicolumn{4}{|c|}{ Labour Productivity } & \multicolumn{4}{|c|}{ TFP } \\
\hline & \multicolumn{2}{|c|}{ 3-DIGIT } & \multicolumn{2}{|c|}{ 4-DIGIT } & \multicolumn{2}{|c|}{ 3-DIGIT } & \multicolumn{2}{|c|}{ 4-DIGIT } \\
\hline & Mean (\%) & Median (\%) & Mean (\%) & Median (\%) & Mean (\%) & Median (\%) & Mean (\%) & Median (\%) \\
\hline$R^{2}$ & 52.95 & 52.81 & 55.22 & 54.91 & 55.69 & 55.18 & 57.92 & 56.98 \\
\hline$S^{2}$ & 14.93 & 14.36 & 15.41 & 14.95 & 16.75 & 16.60 & 16.85 & 16.63 \\
\hline$S_{\Delta}^{2}$ & 13.53 & 12.79 & 13.82 & 13.26 & 15.61 & 15.34 & 15.57 & 15.38 \\
\hline$S_{a}^{2}$ & 1.40 & 1.38 & 1.59 & 1.39 & 1.14 & 1.08 & 1.28 & 1.09 \\
\hline
\end{tabular}

Table 1: Mean and median values of the distributions of $R^{2}, S^{2}, S_{\Delta}^{2}$ and $S_{a}^{2}$ across 161 3-digit sectors and 3934 -digit sectors respectively.

on TFP itself, discussed in Dosi and Grazzi (2006), and more specifically on China in Yu et al. $(2015)) \cdot{ }^{18}$

It is well known that the ownership and governance structures of firms matter in terms of the different corporate growth patterns, and this is particularly true for the case of China (Guariglia et al., 2011). To study how different ownership structures affect the magnitudes of the explanatory power of productivity differentials, we replicate the exercise above after splitting firms within the same 3-digit sector according to the six ownership types (Table 2 and Figure 5). The values of $S^{2}$ of "Shareholding" (State-private joint ventures) and domestic private-owned firms are significantly

\footnotetext{
${ }^{18}$ The details of total factor productivity measure are shown in the Appendix Appendix B.
} 


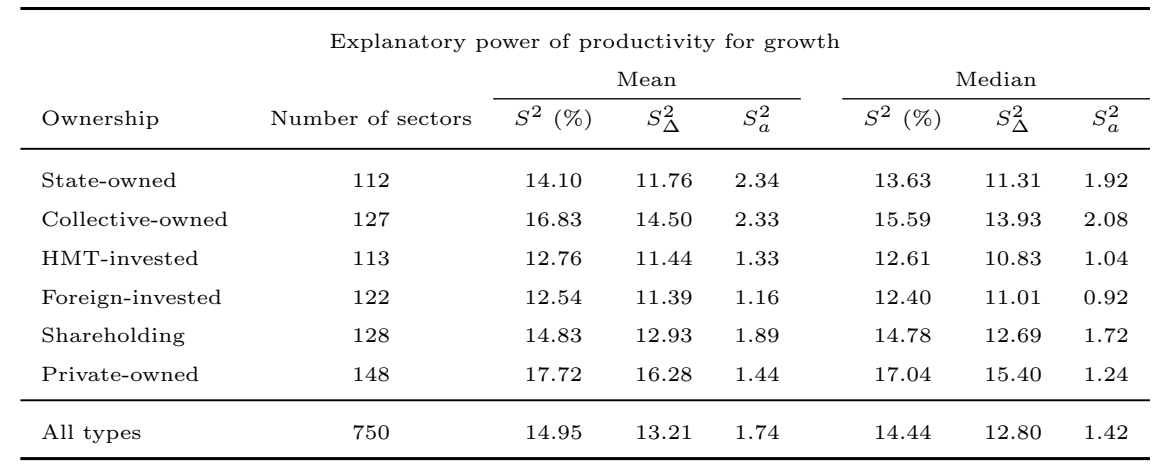

Table 2: Productivity - Growth relationship. Mean and median $S^{2}$ and decomposition of $S^{2}\left(S_{\Delta}^{2}\right.$ and $\left.S_{a}^{2}\right)$ by important ownership types (sectors with the number of firms for each ownership category greater than 200, only). Source: our elaboration on CMM.
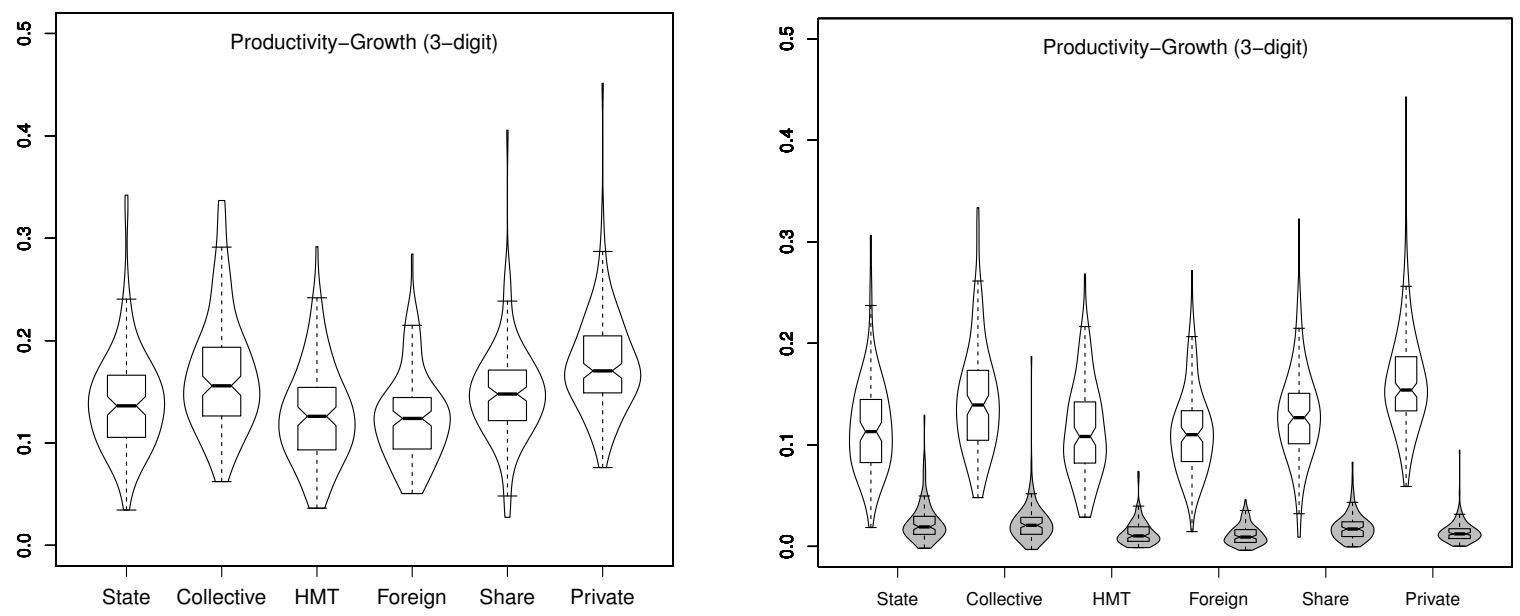

Figure 5: Productivity - Growth relationship. Distributions (left) of $S^{2}$ and decomposition (right) of $S^{2}\left(S_{\Delta}^{2}\right.$ and $\left.S_{a}^{2}\right)$ by important ownership types. The shaded violins refer to $S_{a}^{2}$ and the un-shaded violins refer to $S_{\Delta}^{2}$, as shown in the figure on the right side.

higher than that of the others. Conversely, State-owned and foreign-invested enterprises have significantly lower $S^{2}$, based on ANOVA and post hoc Tukey pairwise comparisons. That is, the selective power of market competition based on firms' relative efficiency is comparatively stronger in private and mixed ownership types, but is weaker among SOEs and foreign-invested firms. Finally, we also investigated whether different "regimes" of technological learning, as captured by the Pavitt taxonomy (Pavitt, 1984), entails differences in the strength of the productivity-growth relation. Results do not support much such hypothesis and are not shown here. 
In the light of the statistical regularities in the coefficients for the current and lagged productivities, one may conjecture that more important drivers of firms growth are productivity variations over time rather than the relative levels of productivity at any time period, as also found in Dosi et al. (2015). In order to test the conjecture, we decompose the $S^{2}$ of productivity into two components, associated respectively with levels and variations, and rewrite Equation (2) as

$$
g_{i, t}=\alpha+\beta_{\Delta} \Delta \pi_{i, t}+\beta_{m} \bar{\pi}_{i, t}+\gamma_{1} S I Z E_{i, t-1}+\gamma_{2} A G E_{i, t-1}+b_{t}+u_{i}+\epsilon_{i, t}
$$

where $\Delta \pi_{i, t}$ is the growth rate of productivity of firm $i\left(\Delta \pi_{i, t}=\pi_{i, t}-\pi_{i, t-1}\right)$, which accounts for the growth of productivity, and $\bar{\pi}_{i, t}$ is the within-firm average productivity level over $t$ and $t-1$ $\left(\bar{\pi}_{i, t}=\frac{1}{2}\left(\pi_{i, t}+\pi_{i, t-1}\right)\right)$, capturing productivity levels. ${ }^{19}$ If firms are selected and grow mostly driven by their relative productivity-level, the explanatory power of $\bar{\pi}_{i, t}$ should be greater than that of $\Delta \pi_{i, t}$, and conversely if the dominant impact is of the rates of change. The estimates continue to be based on a Correlated Random Effects model. ${ }^{20}$ The shaded violins in Figure 4 display the distributions of $S_{\Delta \pi_{i, t}}^{2}$ and $S_{\bar{\pi}_{i, t}}^{2}$ and highlight how the variation of productivity $\left(S_{\Delta \pi_{i, t}}^{2}\right)$ accounts for the largest proportion of $S^{2}$ : the competitive selection mechanism across firms within any one industry appear to be driven to a greater extent by productivity changes rather than relative productivity levels. Note also that this applies to all ownership types, as shown in Figure 5.

To complete the analysis of the virtuous circle we also investigate the relationship between productivities and profitabilities. The results show that the explanatory power of productivityrelated variables to profitabilities is over $20 \%$ (see Figure C.6). The full set of results is reported in Appendix Appendix C.

\section{Profitability and investment}

Let us next investigate the impact of firms' profitability upon growth. Figure 6 shows the relationship between profitability and growth by means of a simple kernel regression. Notice that the kernel fit is flatter than in Figure 2, suggesting that the direct relation between profitability and growth, in any, is much weaker than that found for productivity. This is confirmed by more

\footnotetext{
${ }^{19}$ Hence, $\beta_{0}=\frac{\beta_{m}}{2}+\beta_{\Delta}$ and $\beta_{1}=\frac{\beta_{m}}{2}-\beta_{\Delta}$.

${ }^{20}$ Sectoral (3-digit) results of the decomposition of $S^{2}$ are available upon request.
} 

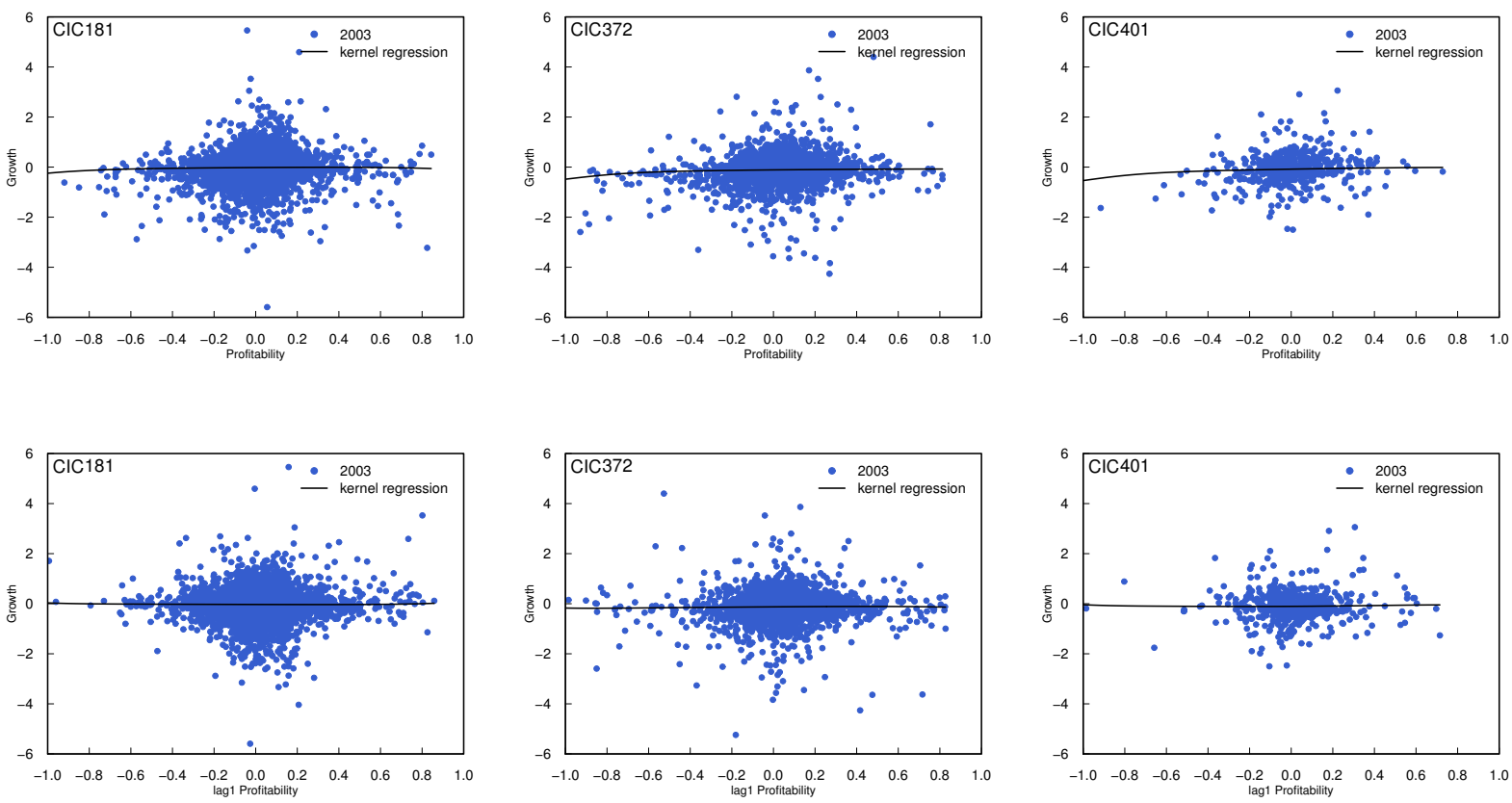

Figure 6: Profitability (gross profit margins) - Growth relationship in selected 3-digit sectors (textile and clothing, automobiles and communication equipment) - kernel regression of 2003. Note: the first row shows current relationship and the second row shows lagged relationship. Source: our elaboration on CMM.

rigorous parametric analysis. To allow for comparability of results we employ the same model as Equation (1). The coefficients of current and lagged profitabilities are statistically significant for the majority of 3 -digit sectors ${ }^{21}$ as shown in Figure 7. However, no strong statistical regularity concerning the signs and values of the coefficients emerges. The median of the overall "fitness" of the model is $46.83 \%$, while the explanatory power $\left(S^{2}\right)$ of profitability variables on growth is 1.93\% (median), as shown in Figure 8. Therefore, firms' unobserved idiosyncratic features appear to explain most of the variance in the (very weak) profitability-growth relationship.

We distinguish firms in each 3-digit sectors by six ownership types and estimate $S^{2}$ for each subsample. The mean and median values of $S^{2}$ are reported in Table 3 and the distributions are shown in Figure 9. Note that, the median $S^{2}$ is very small for all types of firms.

Profitability appears to explain a modest $5 \%$ or less of the variance of growth rates of sales,

\footnotetext{
${ }^{21}$ In the interest of space, detailed tables with sectoral estimates and the related decompositions are not reported here but are available upon request
} 


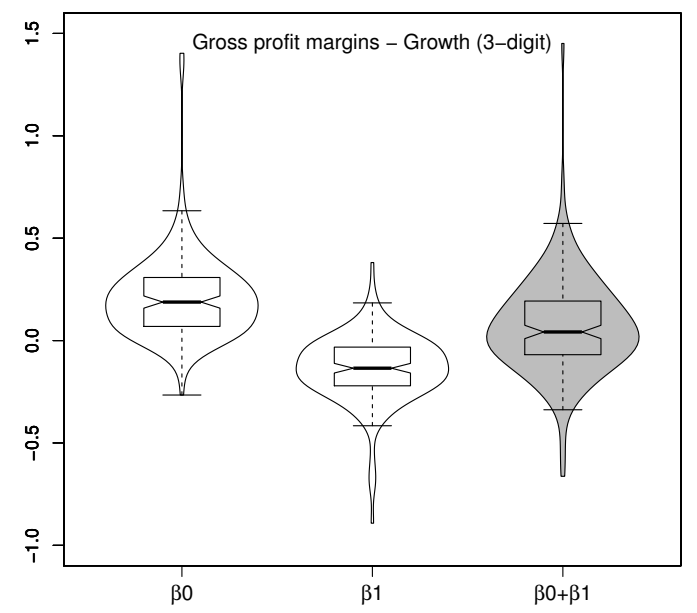

Figure 7: Profitability (gross profit margins) - Growth relationship. Distribution of parameters $\beta_{0}, \beta_{1}$ and $\beta_{0}+\beta_{1}$ of the baseline model, based on 3 digit sectors estimates.

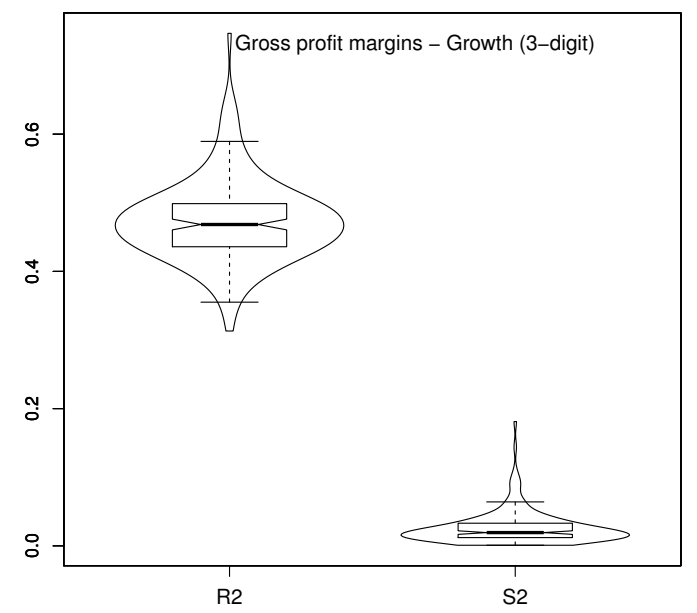

Figure 8: Profitability (gross profit margins) - Growth relationship. Distribution of $R^{2}$ and $S^{2}$, based on 3 digit sectors estimates. $R^{2}$ mean 47.37 , median $46.83 ; S^{2}$ mean 2.62, median 1.93 across 161 3-digit sectors.

which, to recall, is much smaller compared to the $15 \%$ of productivity. Hence we ought to investigate a possible missing link between profitability and growth through the indirect channel of investment in tangible assets, which in turn would spur firm growth.

To our knowledge there does not exist to date a thorough investigation of the investment 


\begin{tabular}{lccc}
\hline \multicolumn{2}{c}{ Explanatory power of profitability } & (gross profit margins) & for growth \\
Ownership & Number of sectors & $S^{2}$-mean (\%) & $S^{2}$-median (\%) \\
\hline State-owned & 112 & 6.95 & 4.81 \\
Collective-owned & 127 & 3.71 & 2.07 \\
HMT-invested & 113 & 3.00 & 2.06 \\
Foreign-invested & 122 & 2.63 & 2.14 \\
Shareholding & 128 & 3.48 & 2.25 \\
Private-owned & 148 & 2.04 & 1.44 \\
\hline All types & 750 & 3.54 & 2.24 \\
\hline
\end{tabular}

Table 3: Profitability (gross profit margins) - Growth relationship. Mean and median $S^{2}$ by important ownership types (sectors with the number of firms for each ownership category greater than 200, only). Source: our elaboration on CMM.

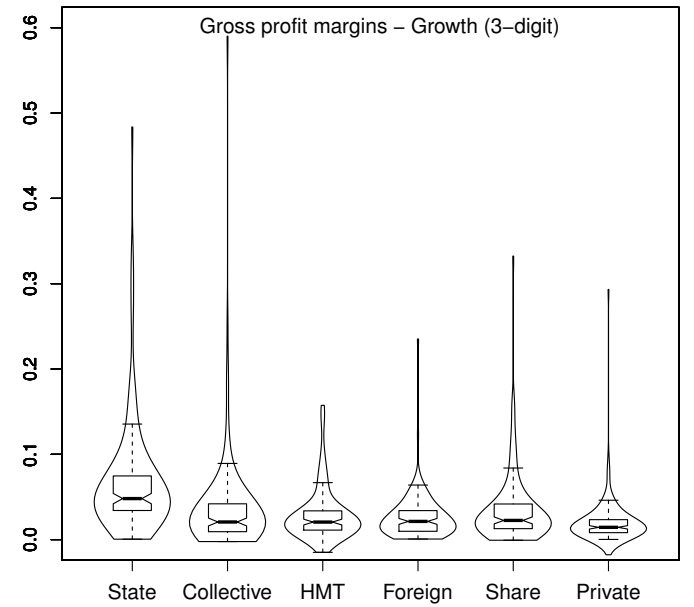

Figure 9: Profitability (gross profit margins) - Growth relationship. Distributions of $S^{2}$ by important ownership types. 

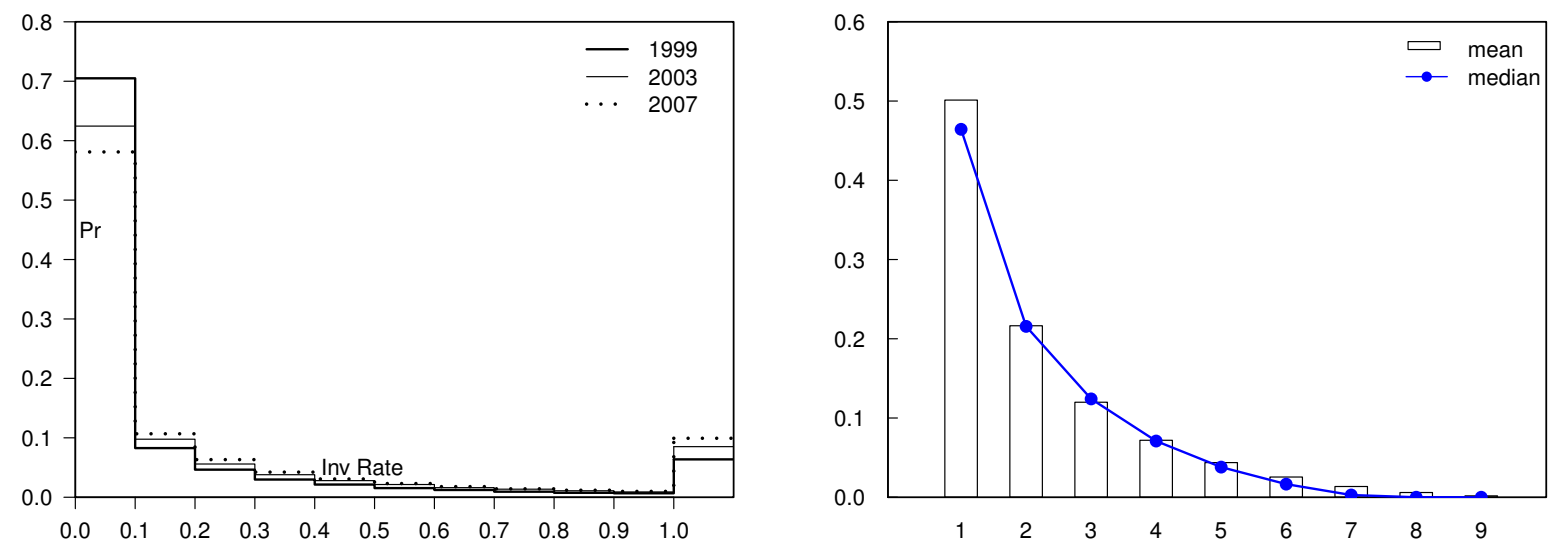

Figure 10: Left: the histogram of investment rates in 1999, 2003 and 2007. Right: the average and median investment shares by rank over the firms in balanced panel (firms existing over the whole period 1998 - 2007). Source: our elaboration on CMM.

patterns in China employing firm level data. Hence we start by looking at the statistical properties of proxies for that variable.

Figure 10 shows the distributions of investment rates, for selected years. For the majority of firms the yearly investment rate is very low, indeed as everywhere in the world: for example, in 1999, over $70 \%$ of firms reported an investment rate of $10 \%$ or lower; $9 \%$ of firms displayed an investment rate of $50 \%$ or more. These patterns are also quite stable over time: in $2007,60 \%$ of firms reported an investment rate of $10 \%$ or lower; $15 \%$ of firms displayed an investment rate of $50 \%$ or more. Inactivity (zero investment) also occurs quite often: about $33.7 \%$ of the investment observations are zeros.

Figure 10 also displays our (admittedly noisy) proxy for firms' investment over time. If we were to observe that, on average, the profile of annual firm-level investment were rather flat, that would corroborate the conjecture of a smooth process of capital adjustment at the firm level. The opposite is true if we were to observe spikes in such firm level patterns. For each firm, we rank the investment shares for the period 1998-2007 and then we compute the average (median) for each rank over all the firms in the balanced panel. The highest investment share on average accounts 


\begin{tabular}{|c|c|c|c|c|c|c|c|c|c|c|c|c|}
\hline & All & 1 & 0 & All & 1 & 0 & All & 1 & 0 & All & 1 & 0 \\
\hline & 1999 & & & 2003 & & & 2007 & & & $99-07$ & & \\
\hline Mean invest. rate & 0.16 & 0.81 & 0.04 & 0.22 & 0.96 & 0.06 & 0.24 & 1.03 & 0.08 & 0.22 & 0.98 & 0.07 \\
\hline Median invest. rate & 0.01 & 0.59 & 0.00 & 0.03 & 0.75 & 0.01 & 0.05 & 0.83 & 0.02 & 0.03 & 0.77 & 0.01 \\
\hline$\%$ of spikes in \# of obs. & 15.80 & & & 17.20 & & & 17.29 & & & 17.06 & & \\
\hline $\begin{array}{l}\% \text { of total invest. } \\
\text { accounted by spikes }\end{array}$ & 66.06 & & & 68.83 & & & 66.99 & & & 67.21 & & \\
\hline
\end{tabular}

Table 4: Descriptive statistics of investment spikes (kernel rule). Note: $S_{i, t}=1$ denotes the subsample of investment spikes, and $S_{i, t}=0$ denotes the subsample of non-spike observations. Source: our elaboration on CMM.

for $50 \%$ of total investment during the nine years. ${ }^{22}$ Firms concentrate $80 \%$ of investment in three years, while investment shares are significantly lower in other years, revealing a major lumpiness of the investment behavior. This confirms, of course, previous results on the dynamics of firms investments (see among the others Doms and Dunne, 1998)).

Hence, in the following we will focus on investment spikes (see also Power, 1998; Nilsen et al., 2009), because only very large investments episodes are likely to be accompanied by the expansion of production capacity, which, in turn, is closely linked to firm growth. As a result, only investment rate above a certain threshold will be classified as spikes. There are some criteria that guide the choice among different spike measures. As put forth in Nilsen et al. (2009) the investment must be large both respect to the history of the firm and to the cross section at averages of the industry. Further, it has to be a relatively rare event. Overall the definition of the spike must be able to account for a relevant share of total industry investment. ${ }^{23}$

In this work, we employ a non parametric methodology that, in order to identify firm level spikes, resort to the kernel estimate of the relation between investment and capital stock (Grazzi et al., forthcoming). Details are reported in the Appendix D. Descriptive statistics for kernel method are reported in Table 4: over the whole sample period, $17 \%$ of observations are classified as spikes and they account for $67 \%$ of total investment. Table 5 and 6 show how investment spikes and investment shares are distributed across ownership classes and how such shares change over

\footnotetext{
${ }^{22}$ Investment is deflated by price index.

${ }^{23}$ Nilsen et al. (2009) also hint at the necessity to account for the relationship that might exist between the investment rate and the capital stock. According to NBSC, the book value is the sum of nominal values for different years. We calculate the real capital stock using the perpetual inventory method, assuming a depreciation rate of $9 \%$ and deflate it.
} 


\begin{tabular}{lrrrrrrrrrr}
\hline Ownership & 1999 & 2000 & 2001 & 2002 & 2003 & 2004 & 2005 & 2006 & 2007 & All period \\
\hline State-owned & 17.47 & 14.10 & 10.81 & 6.97 & 4.98 & 3.27 & 2.03 & 1.80 & 1.45 & 5.39 \\
Collective-owned & 38.77 & 33.89 & 26.05 & 20.79 & 15.46 & 9.13 & 7.02 & 5.54 & 4.53 & 14.25 \\
HMT-invested & 11.11 & 12.36 & 12.98 & 11.85 & 11.02 & 11.87 & 9.91 & 9.79 & 9.23 & 10.71 \\
Foreign-invested & 8.25 & 9.15 & 10.71 & 9.63 & 10.32 & 13.10 & 11.86 & 11.48 & 10.75 & 10.80 \\
Shareholding & 10.86 & 12.92 & 15.64 & 17.48 & 17.99 & 18.95 & 17.37 & 17.42 & 16.60 & 16.51 \\
Private-invested & 12.69 & 16.71 & 22.98 & 32.60 & 39.69 & 43.35 & 51.27 & 53.57 & 57.05 & 41.78 \\
Other domestic & 0.85 & 0.86 & 0.83 & 0.68 & 0.53 & 0.32 & 0.55 & 0.41 & 0.40 & 0.55 \\
\hline Total \% & 100 & 100 & 100 & 100 & 100 & 100 & 100 & 100 & 100 & 100 \\
\hline
\end{tabular}

Table 5: Distribution of investment spikes by ownership types. Source: our elaboration on CMM.

\begin{tabular}{lrrrrrrrrrr}
\hline Ownership & 1999 & 2000 & 2001 & 2002 & 2003 & 2004 & 2005 & 2006 & 2007 & All period \\
\hline State-owned & 51.50 & 41.16 & 30.35 & 22.08 & 21.36 & 13.13 & 16.88 & 13.51 & 12.77 & 20.58 \\
Collective-owned & 12.53 & 12.45 & 9.31 & 9.14 & 8.28 & 3.99 & 3.51 & 3.21 & 2.97 & 5.78 \\
HMT-invested & 9.52 & 10.71 & 9.97 & 11.92 & 10.13 & 11.41 & 9.63 & 10.91 & 10.51 & 10.50 \\
Foreign-invested & 10.23 & 13.52 & 14.81 & 13.98 & 15.95 & 20.95 & 19.83 & 20.96 & 21.30 & 18.29 \\
Shareholding & 12.87 & 17.13 & 29.22 & 32.00 & 30.16 & 35.22 & 31.92 & 30.65 & 29.49 & 29.03 \\
Private-owned & 2.96 & 4.60 & 5.84 & 10.51 & 13.88 & 15.10 & 17.78 & 20.59 & 22.66 & 15.50 \\
Other domestic & 0.40 & 0.45 & 0.50 & 0.37 & 0.25 & 0.19 & 0.45 & 0.17 & 0.32 & 0.33 \\
\hline Total \% & 100 & 100 & 100 & 100 & 100 & 100 & 100 & 100 & 100 & \multirow{2}{*}{100} \\
\hline
\end{tabular}

Table 6: Distribution of investment shares by ownership types. Source: our elaboration on CMM.

time. In 1999 around $17.5 \%$ of relevant investment episodes were classified as investment spikes of State-owned enterprises and such events accounted for around half of total investment. ${ }^{24}$ The decline over time of State-owned enterprises is well accounted by their shrinking share of both investment spikes and total investment. On the contrary, private-owned enterprises display the opposite trend, accounting for an increasing proportion of both spikes and investment shares.

We next turn to investigate how firm's profitability impact the investment patterns. Conditional on firm's past investment behavior and on average investment behavior over the sample, what is the role of current and past profitabilities in shaping the capital adjustment patterns? The baseline model for estimating the relationship between profitability and investment employs autoregressive distributed-lags of length $m$

$$
y_{i, t}=\alpha+\sum_{s=1}^{S} \beta_{s} y_{i, t-s}+\sum_{k=0}^{K} \gamma_{k} x_{i, t-k}+b_{t}+c_{j}+u_{i}+\epsilon_{i, t}
$$

where $y_{i, t}$ denotes investment rate of firm $i$ at time $t ; y_{i, t-s}$ represents investment rate at time

\footnotetext{
${ }^{24}$ Due to the large size of State-owned enterprises, a few large investment episodes of this category of firms accounts for a much larger share of total investment.
} 
$t-s ; x_{i, t-k}$ denotes profitability at time $t-k ; u_{i}$ is a correlated firm effect; $b_{t}$ are year dummies; $c_{j}$ are 2-digit sector dummies, and $\epsilon_{i, t}$ is a serially uncorrelated disturbance. Since our variable of

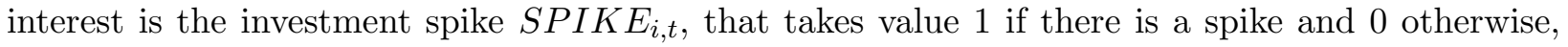
we estimate the refinement upon our baseline model

$S P I K E_{i, t}=\alpha+\beta_{0} P_{i, t}+\beta_{1} P_{i, t-1}+\beta_{2} P_{i, t-2}+\beta_{3} P_{i, t-3}+\gamma_{1} D_{i,-1}+\gamma_{2} D_{i,-2}+\gamma_{3} D_{i,-3}+b_{t}+c_{j}+u_{i}+\epsilon_{i, t}$

where $P_{i, t}, P_{i, t-1}, P_{i, t-2}$ and $P_{i, t-3}$ are contemporaneous and lagged profitabilities and $D_{i,-1}$, $D_{i,-2}$ and $D_{i,-3}$ are duration dummies capturing the time elapsed since last spike. $D_{i,-1}$ takes value 1 if there is a spike in year $t-1 . D_{i,-2}$ takes value 1 if there is a spike in year $t-2$ but not in $t-1$. $D_{i,-3}$ is 1 if there is a spike in year $t-3$ but not in $t-2$ or $t-1$. These dummy variables capture the effect of the length of the interval from the last high-investment episode on the probability of having a spike in year $t$ (cf. Cooper et al., 1999; Grazzi et al., forthcoming; Bigsten et al., 2005). $u_{i}$ is a firm-specific unobserved effect and $\epsilon_{i, t}$ is a serially uncorrelated logistic disturbance term. Time (year) and sectoral (2-digit) dummies are also included in the regression. ${ }^{25}$

The effect of profitability on the probability of having a spike in year $t$ is reported in Table 7. The results of random effect logistic regression are reported in the first two columns. The coefficients of current and lagged profitabilities are jointly significant, suggesting that investment spikes are sensitive to profitability. As expected, the findings signal that internal and external sources of finance are not perfectly substitutable. To get an idea of the order of magnitude, a $1 \%$ increase in profitability is related to $1.4 \%$ increase in the odds of reporting an investment spike when considering the sum of the coefficients of contemporaneous and lagged profitabilities. ${ }^{26}$ Also notice that the negative effect of past investment spikes on the probability of having current investment spike decreases with time.

We also estimate the profitability-investment model (Equation (7)) for each ownership type

\footnotetext{
${ }^{25}$ After some experimentation and after comparing the AIC and BIC criteria of the models, we decide to include three lags of profitability.

${ }^{26}$ The sum of the coefficients of contemporaneous and lagged profitabilities is 1.37, which is the log-odds ratio. Thus, a $1 \%$ increase in profitability will induce $e^{0.01 \times 1.37}-1=0.0138$ increase in the odds of having a spike. Odds refers to the ratio between the probability of having a spike and the probability of not having a spike.
} 


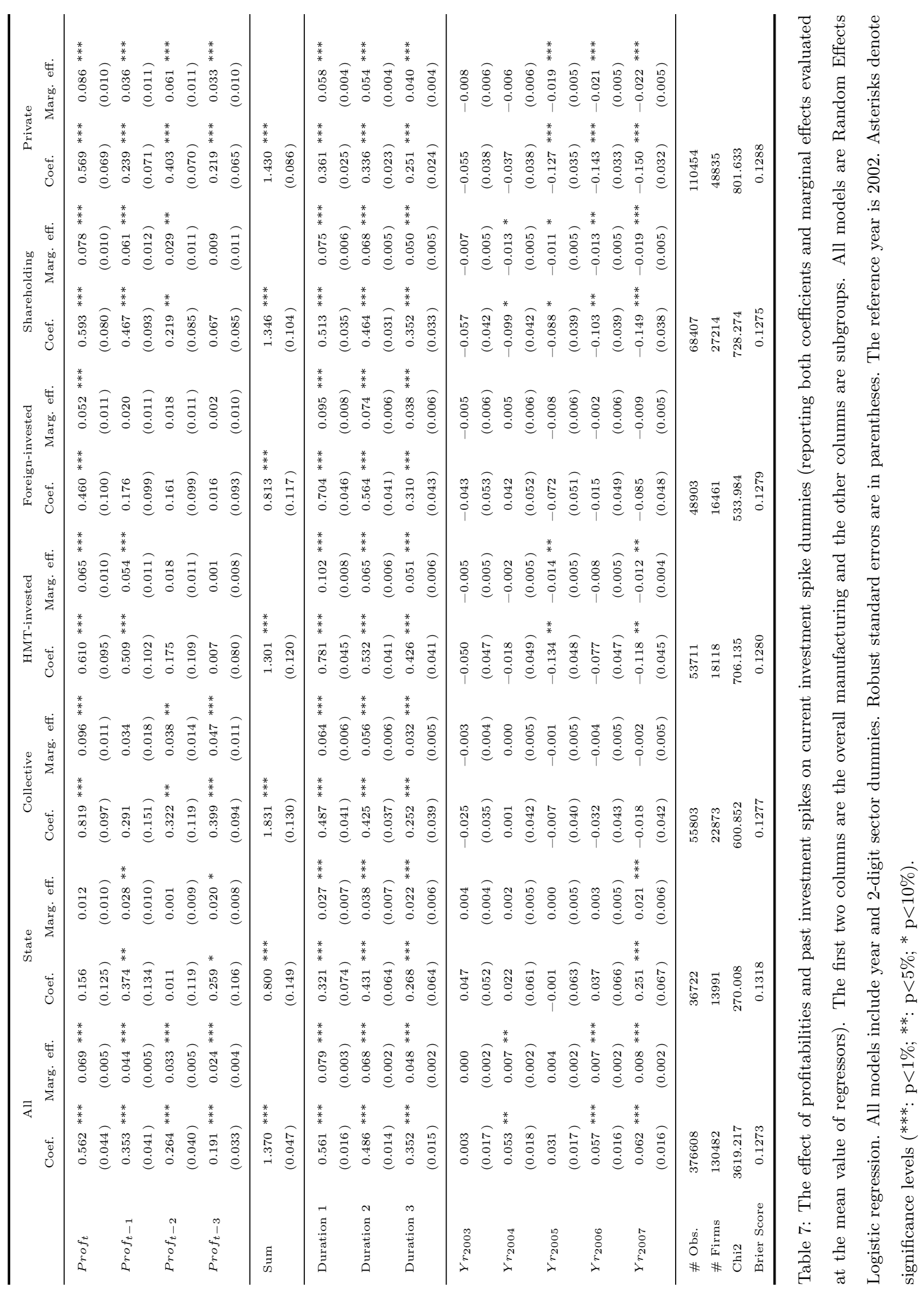



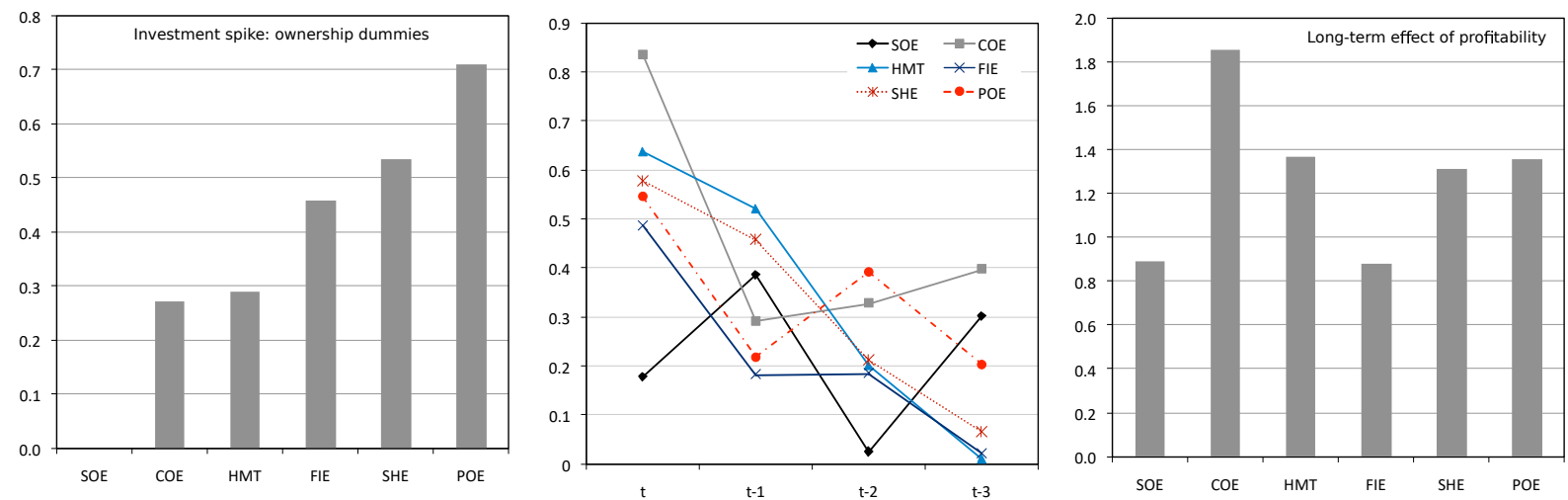

Figure 11: The estimated coefficients of Equation (8) using random effects logistic regression. Left: the coefficients of ownership type dummies. Middle: the coefficients of current and lagged profitabilities across ownership types. Right: the sum of the coefficients of current and lagged profitabilities by ownership types.

respectively. Results show that the magnitudes of the coefficients of profitability differ across ownership types (see Table 7). In particular it appears that State-owned enterprises is the only category of firms displaying a non-significant relation between same-year profitability and likelihood to report an investment spike.

The evidence collected so far has shown that the ownership types influence several characteristics of the firm, as well as its dynamics. In order to test directly how the effect of profitabilities on the likelihood of a spike changes across ownership types, we add the related interaction terms as follows

$$
\begin{aligned}
S P I K E_{i, t}= & \alpha+\beta_{0} P_{i, t}+\beta_{1} P_{i, t-1}+\beta_{2} P_{i, t-2}+\beta_{3} P_{i, t-3}+J_{i, t} \\
& +\delta_{0}\left(P_{i, t} \times J_{i, t}\right)+\delta_{1}\left(P_{i, t-1} \times J_{i, t}\right)+\delta_{2}\left(P_{i, t-2} \times J_{i, t}\right)+\delta_{3}\left(P_{i, t-3} \times J_{i, t}\right) \\
& +\gamma_{1} D_{i,-1}+\gamma_{2} D_{i,-2}+\gamma_{3} D_{i,-3}+b_{t}+c_{j}+u_{i}+\epsilon_{i, t}
\end{aligned}
$$

where $J_{i, t}$ is the ownership type dummies (i.e., six ownership categories. State-owned enterprises as the reference group).

Figure 11 summarize the regression results and the comparative evidence across ownership types on the effects of profitabilities on investment spikes. ${ }^{27}$ The long-term effects of profitability (the

\footnotetext{
${ }^{27}$ The regression results are available upon request.
} 
sum of the effects of contemporaneous and lagged profitabilities) are the highest for collectiveowned, shareholding and domestic private-owned enterprises. ${ }^{28}$ In contrast, the large investment projects of State-owned and foreign-invested enterprises are less sensitive to profitabilities (i.e. cash flows). Interestingly, even though the large investment projects undertaken by domestic privateowned enterprises are highly constrained by their profitability, they show the highest propensity to undertake them.

\section{Investment spike and firm growth}

Investments in equipment embodying the latest technology is one of the drivers of productivity growth and plausibly, together, firm growth. In this respect, investment represents a further channel for the efficiency-driven competitive selection process. Mitigating that, it might also happen that very large investment episodes are associated with the disruption of consolidated production processes and existing organizational routines, thus having a (short-term) negative effect on productivity before yielding a long learning curve. In particular, the recent empirical evidence (see for instance Power, 1998) has shown that the occurrence of negative effects following a spike is not a rare event, especially in the first years following the large investment episode.

To assess the effect of investment spike on firm performance we estimate the model

$$
X_{i, t}=\beta_{0} D t 0_{i, t}+\beta_{2} D t 1_{i, t}+\beta_{3} D t 2_{i, t}+\gamma_{1} \text { DBefore }_{i, t}+b_{t}+c_{j}+u_{i}+\epsilon_{i, t}
$$

where $X_{i, t}$ is one of the three performance variables under our investigation (productivity level/growth or sales growth) and $D t 0_{i, t}, D t 1_{i, t}, D t 2_{i, t}$ are duration dummies. $D t 0_{i, t}$ takes value 1 if the investment spike is contemporaneous, occurring in year $t ; D t 1_{i, t}$ is 1 if the investment took place at $t-1$, but not in $t$, and $D t 2_{i, t}$ takes value 1 if the spike occurred at $t-2$, but not in $t-1$ or in $t$. DBefore $e_{i, t}$ is a dummy taking value one if the last investment spike was observed more than two years before $t$ and zero otherwise, hence, the coefficient $\gamma_{1}$ accounts for the effect of investment spikes on firm performance in the long run. $u_{i}$ is a firm-specific unobserved random-effect and $\epsilon_{i, t}$ is the error term. $b_{t}$ are time dummies and $c_{j}$ are 2-digit sectoral dummies.

\footnotetext{
${ }^{28}$ Note that the share of collective-owned enterprises decreased dramatically towards the end of the period of investigation due to the ownership transformation process (see Yu et al., 2015).
} 
In analogy with the previous section, we also include interacted terms so that it is possible to make direct comparison of the effects of investment spikes on firm performances across different ownership types, and we estimate the following model

$$
\begin{aligned}
X_{i, t}= & \beta_{0} D t 0_{i, t}+\beta_{1} D t 1_{i, t}+\beta_{2} D t 2_{i, t}+\gamma_{1} \text { DBefore }_{i, t}+J_{i, t} \\
& +\delta_{0}\left(D t 0_{i, t} \times J_{i, t}\right)+\delta_{1}\left(D t 1_{i, t} \times J_{i, t}\right)+\delta_{2}\left(D t 2_{i, t} \times J_{i, t}\right)+\left(\delta_{3} \text { DBefore }_{i, t} \times J_{i, t}\right) \\
& +b_{t}+c_{j}+u_{i}+\epsilon_{i, t}
\end{aligned}
$$

where $J_{i, t}$ denotes the ownership type dummies.

Table 8 reports the estimates of the effects of investment spikes on productivity level. The contemporaneous investment spike induce a $9.2 \%$ increase in productivity level; while an investment spike occurred more than three years before induce a $3.5 \%$ increase in current productivity level, thus, hinting at a higher impact of contemporaneous spikes. Investments in tangible assets seem to be able to deploy their effect on productivity since their very adoption. Notice that the positive effect of investment spikes on productivity levels decreases with the time elapsed from last investment spike.

To give a preview of whether the effects of investment spikes on productivity level vary across ownership types, we also test Model (9) for each subsample of firms in terms of their ownership structures and the last six columns of Table 8 reveal that both the magnitudes and the dynamic patterns of the effect of investment spikes differ over ownership types.

Based on the fixed effects estimates of Equation (10), Figure 12 shows the effects of investment on productivity levels conditional on ownership types. A contemporaneous investment spike will induce a 13-15\% increase in productivity level for State-owned and domestic private-owned enterprises (even if SOEs and POEs show relatively lower productivity level), while it will not induce any increase in productivity level for HMT- or foreign-invested firms, and their past investment spikes might even have negative effects on productivity level (see the graph on the right side of Figure 12).

The first column of Table 9 shows the effect of investment spikes on growth of sales. The effect of contemporaneous investment spikes on firm growth is the largest $(10.2 \%)$ and drops significantly afterwards. Moreover, a contemporaneous investment spike yields a $14 \%$ increase in sales growth 


\begin{tabular}{|c|c|c|c|c|c|c|c|}
\hline & \multicolumn{7}{|c|}{ Dependent variable: Level of productivity } \\
\hline & All manufacturing & State-owned & Collective-owned & HMT-invested & Foreign-invested & Shareholding & Private-owned \\
\hline D0 & $\begin{array}{l}0.092 * * * \\
(0.008)\end{array}$ & $\begin{array}{l}0.082 * * \\
(0.030)\end{array}$ & $\begin{array}{l}0.116 * * * \\
(0.021)\end{array}$ & $\begin{array}{l}0.063 * * \\
(0.021)\end{array}$ & $\begin{array}{l}0.055 * \\
(0.023)\end{array}$ & $\begin{array}{l}0.092^{* * *} \\
(0.019)\end{array}$ & $\begin{array}{l}0.062 * * * \\
(0.015)\end{array}$ \\
\hline D1 & $\begin{array}{l}0.083 \text { *** } \\
(0.009)\end{array}$ & $\begin{array}{c}0.062 \\
(0.034)\end{array}$ & $\begin{array}{l}0.118 * * * \\
(0.023)\end{array}$ & $\begin{array}{c}0.040 \\
(0.023)\end{array}$ & $\begin{array}{c}0.040 \\
(0.024)\end{array}$ & $\begin{array}{l}0.088 * * * \\
(0.020)\end{array}$ & $\begin{array}{l}0.055^{* * *} \\
(0.016)\end{array}$ \\
\hline D2 & $\begin{array}{l}0.068 * * * \\
(0.009)\end{array}$ & $\begin{array}{c}0.054 \\
(0.037)\end{array}$ & $\begin{array}{l}0.082 * * \\
(0.025)\end{array}$ & $\begin{array}{c}0.047 \\
(0.024)\end{array}$ & $\begin{array}{c}0.042 \\
(0.026)\end{array}$ & $\begin{array}{l}0.060 * * \\
(0.021)\end{array}$ & $\begin{array}{c}0.031 \\
(0.017)\end{array}$ \\
\hline DBefore & $\begin{array}{l}0.035 * * * \\
(0.010)\end{array}$ & $\begin{array}{c}0.006 \\
(0.040)\end{array}$ & $\begin{array}{l}0.052 * \\
(0.027)\end{array}$ & $\begin{array}{c}0.033 \\
(0.026)\end{array}$ & $\begin{array}{c}0.002 \\
(0.027)\end{array}$ & $\begin{array}{c}0.020 \\
(0.023)\end{array}$ & $\begin{array}{c}0.003 \\
(0.019)\end{array}$ \\
\hline \# Obs. & 376653 & 36759 & 55806 & 53711 & 48903 & 68412 & 110454 \\
\hline \# Firms & 130498 & 14005 & 22875 & 18118 & 16461 & 27215 & 48835 \\
\hline R2 within & 0.050 & 0.040 & 0.057 & 0.019 & 0.019 & 0.057 & 0.097 \\
\hline $\mathrm{R} 2$ between & 0.105 & 0.044 & 0.051 & 0.061 & 0.020 & 0.083 & 0.026 \\
\hline $\mathrm{R} 2$ overall & 0.063 & 0.043 & 0.044 & 0.049 & 0.013 & 0.061 & 0.027 \\
\hline
\end{tabular}

Table 8: Effects of Investment on levels of productivity. Note: All models are Fixed Effects regressions. Year and 2-digit sectoral dummies are included, 2002 is the reference year. Robust standard errors are in parentheses. Asterisks denote significance levels (***: $\mathrm{p}<1 \%$; *: $\mathrm{p}<5 \%$; $\mathrm{p}<10 \%)$.
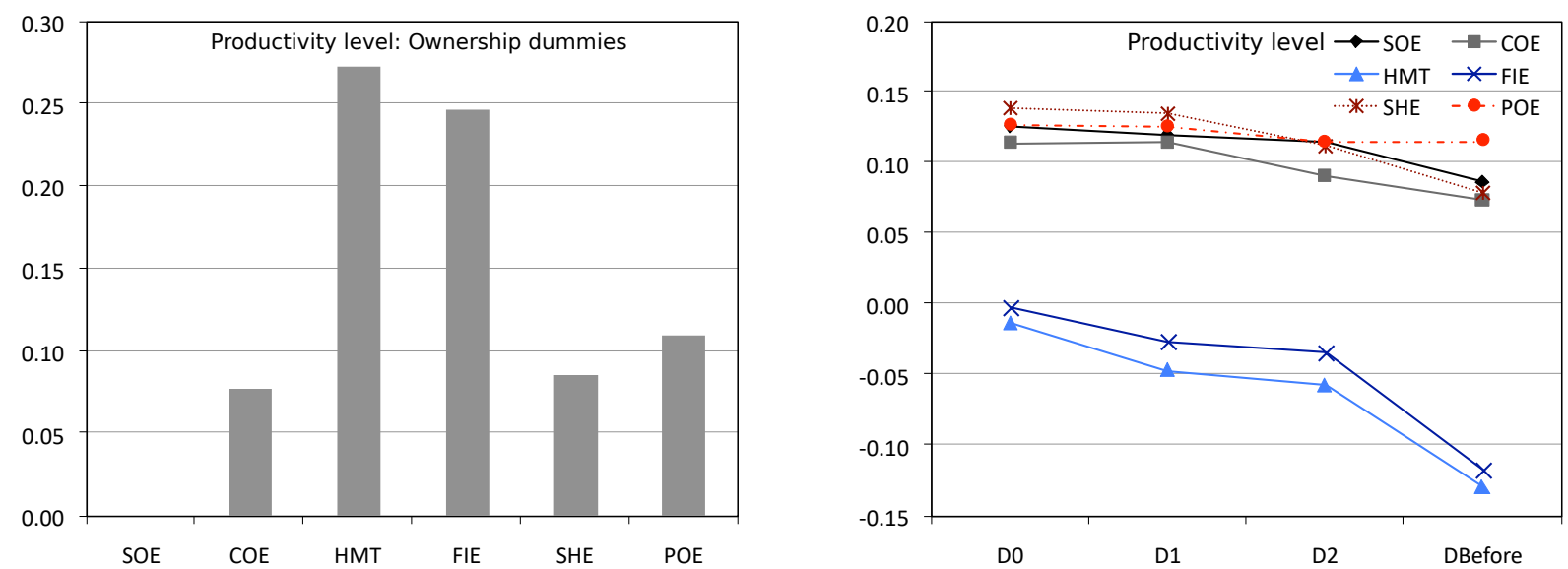

Figure 12: Left: effects of ownership dummies on productivity level. Note: SOE is the reference group. Right: the effects of investment spike timing on labour productivity level conditional on ownership types.

compared with only a $8 \%$ increase for foreign-invested firms (see Figure 13).

\section{Final remarks}

The whole virtuous circle driving industrialization and catching-up has many rich microeconomic facets which one is only beginning to explore. This paper contributes to that exploration in the case of China, an outstanding case of a rapid continent-wide Great Transformation.

Indeed, the major underlying driving force appears to be learning, that is the accumulation 


\begin{tabular}{|c|c|c|c|c|c|c|c|}
\hline & \multicolumn{7}{|c|}{ Dependent variable: Growth of Sales } \\
\hline & All manufacturing & State-owned & Collective-owned & HMT-invested & Foreign-invested & Shareholding & Private-owned \\
\hline \multirow[t]{2}{*}{ Do } & $0.102 * * *$ & $0.113 * * *$ & $0.096 * * *$ & $0.094 * * *$ & $0.089 * * *$ & $0.117 * * *$ & $0.090 * * *$ \\
\hline & $(0.006)$ & $(0.025)$ & $(0.014)$ & $(0.014)$ & $(0.013)$ & $(0.015)$ & $(0.011)$ \\
\hline \multirow[t]{2}{*}{ D1 } & 0.005 & -0.032 & 0.001 & 0.008 & 0.013 & 0.024 & -0.015 \\
\hline & $(0.006)$ & $(0.026)$ & $(0.015)$ & $(0.014)$ & $(0.013)$ & $(0.015)$ & $(0.011)$ \\
\hline \multirow[t]{2}{*}{ D2 } & $-0.012 *$ & $-0.065 *$ & -0.019 & -0.009 & 0.000 & -0.006 & -0.023 \\
\hline & $(0.006)$ & $(0.027)$ & $(0.016)$ & $(0.014)$ & $(0.014)$ & $(0.016)$ & $(0.012)$ \\
\hline \multirow[t]{2}{*}{ DBefore } & -0.010 & -0.045 & -0.023 & 0.000 & -0.007 & 0.005 & -0.022 \\
\hline & $(0.006)$ & $(0.029)$ & $(0.017)$ & $(0.016)$ & $(0.015)$ & $(0.017)$ & $(0.013)$ \\
\hline \# Obs. & 376653 & 36759 & 55806 & 53711 & 48903 & 68412 & 110454 \\
\hline \# Firms & 130498 & 14005 & 22875 & 18118 & 16461 & 27215 & 48835 \\
\hline R2 within & 0.012 & 0.011 & 0.012 & 0.015 & 0.015 & 0.013 & 0.014 \\
\hline $\mathrm{R} 2$ between & 0.000 & 0.004 & 0.000 & 0.001 & 0.003 & 0.003 & 0.006 \\
\hline R2 overall & 0.007 & 0.000 & 0.002 & 0.006 & 0.010 & 0.005 & 0.010 \\
\hline
\end{tabular}

Table 9: Effect of Investment on growth of sales. Note: All models are Fixed Effects regression. Column one is the overall manufacturing and the other columns are subgroups. Year and 2-digit sectoral dummies are included, 2002 is the reference year. Robust standard errors are in parentheses. Asterisks denote significance levels $(* * *: \mathrm{p}<1 \%$; $* *$ : $\mathrm{p}<5 \% ; * \mathrm{p}<10 \%)$.

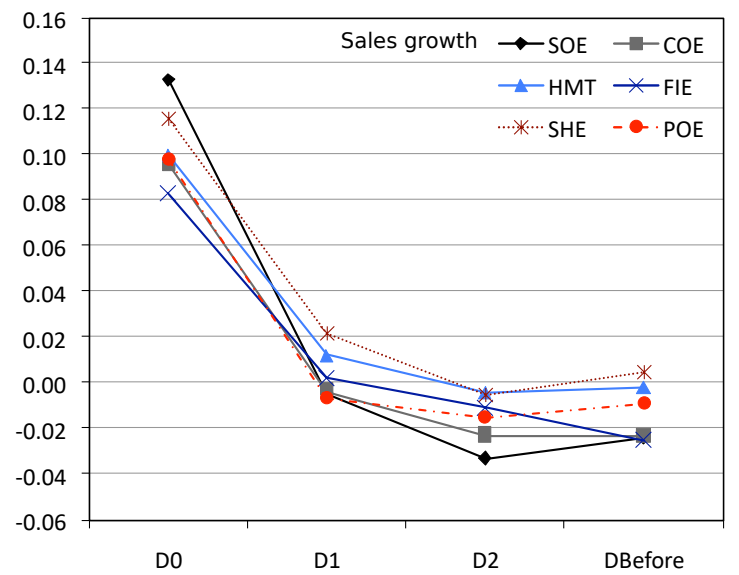

Figure 13: The effects of investment spike timing on sales growth conditional on ownership types.

of technological and organizational capabilities yielding imitation, efficiency improvements and, eventually, innovation (see, in general, Cimoli et al. (2009) and, specifically on China Yu et al. (2015)). However, the ways such learning translates into corporate growth is somewhat more indirect and roundabout.

Our analysis reveals a few aspects of the "microeconomics of virtuous circle". More efficient firms grow more, but not so much more. Market selection operates in the "right" direction, but in China as well as in fully industrialized countries, it appears to be relatively mild in its effects. 
That is, in an evolutionary language, (firm-specific) learning appears to be a much more powerful driver of industrial dynamics than sheer market competition and selection.

This paper contributes to the literature on the market selection mechanism in an emerging market by exploring the extent to which firm growth rates are shaped by a) relative productivity levels and productivity variations, and b) profitability-related variables, respectively.

We find that, first, in both mechanisms, firms' fixed idiosyncratic "strategic orientations" play a prominent role in explaining the different patterns of firms growth.

Second, we have shown that productivity also greatly contributes to the "explanation" of firm growth. However it is the growth of productivity that accounts for a substantial portion of overall variance of firm growth rates, while firm's relative productivity levels seem to contribute less. As they argue at much greater length in Dosi et al. (2015), this finding is coherent with a statistical setup in which different submarkets are aggregated in the "same" industrial sector. Firms located in different submarkets do not compete over the same products. Fiat and Volkswagen do not compete with Ferrari, Jaguar and Lamborghini. But they are all aggregated into the same "sector". As a consequence, however, mean productivities do not mean much. Thus, their different absolute levels of efficiency do not actually matter in explaining their different growth rates. What reveals some noisy competitive dynamics, on the contrary, is the dynamics on the relative levels of productivity themselves.

Quite interestingly, our results show that the productivity-growth link is stronger for the most dynamic firms of the Chinese economy, which often happen to be State-private joint ventures (shareholding enterprises).

Third, more generally the institutional set-ups matter a lot. They matter in terms of access to finance. And they matter also in terms of strategic orientations, forms of corporate governance, and ultimately growth performance. In the Chinese experience, there is some circumstantial evidence that State-owned enterprises appear to enjoy the softer financial budget constraints. However, State-private joint ventures turn out to be at the heart of Chinese industrialization in terms of productivity growth, placement among the most dynamic sectors and output growth.

Fourth, the direct contribution of profitability-related variables to growth is quite small even if not absent. The positive association between profitability and investment is as such evidence of the existence of financial constraints and financial market imperfection. In turn, investment spikes 
have a positive and significant effect on firms' productivity, both in levels and growth rates, and the effect on sales growth is even bigger.

Taken together these results provide evidence in support of the mediating role of investment for firm growth, but, more generally, add to the anatomy of the roundabout ways the "virtuous circle" works. Learning - captured here by the microeconomic dynamics of productivity growth -, and, relatedly, innovation (we conjecture, in absence of direct proxies) are the perpetual motor of such virtuous dynamics fuelling and being fuelled by corporate investment and growth.

\section{Acknowledgements}

We thank several participants to the DRUID Academy Conference, Aalborg, January 2014; the 3rd Pacific Rim Conference, Waikoloa, May 2014; the 13th EACES Biennial Conference, Budapest, September 2014; the 11th ENEF Workshop, Manchester, September 2014; the 1st World Congress of Comparative Economics, Rome, June 2015; and two anonymous referees for their valuable comments. We gratefully acknowledge the support by the European Union Horizon 2020 Research and Innovation programme under grant agreement No. 649186 - ISIGrowth. The usual disclaimer applies.

\section{References}

Allen, F., J. Qian, C. Zhang, M. Zhao, et al. (2012). China's financial system: opportunities and challenges. In Capitalizing China, pp. 63-143. Chicago: University of Chicago Press.

Arellano, M. (2003). Panel Data Econometrics. Oxford: Oxford University Press.

Asphjell, M. K., W. Letterie, Ø. A. Nilsen, and G. A. Pfann (2014). Sequentiality versus simultaneity: interrelated factor demand. Review of Economics and Statistics 96(5), 986-998.

Audretsch, D. B. and J. A. Elston (2002). Does firm size matter? Evidence on the impact of liquidity constraints on firm investment behavior in Germany. International Journal of Industrial Organization 20(1), $1-17$.

Bartelsman, E. J. and M. Doms (2000). Understanding productivity: lessons from longitudinal microdata. Journal of Economic Literature 38(2), 569-594. 
Bigsten, A., P. Collier, S. Dercon, M. Fafchamps, B. Gauthier, J. Gunning, R. Oostendorp, C. Pattillo, M. Soderbom, and F. Teal (2005). Adjustment costs and irreversibility as determinants of investment: evidence from African manufacturing. Contributions to Economic Analysis and Policy 4(1), 1-27.

Bottazzi, G., G. Dosi, N. Jacoby, A. Secchi, and F. Tamagni (2010). Corporate performances and market selection: some comparative evidence. Industrial and Corporate Change 19(6), 1953-1966.

Bottazzi, G., G. Dosi, and G. Rocchetti (2001). Modes of knowledge accumulation, entry regimes and patterns of industrial evolution. Industrial and Corporate Change 10(3), 609-638.

Brandt, L., J. Van Biesebroeck, and Y. Zhang (2012). Creative accounting or creative destruction? Firm-level productivity growth in Chinese manufacturing. Journal of Development Economic 97(2), 339-351.

Brown, J. R., S. M. Fazzari, and B. C. Petersen (2009). Financing innovation and growth: cash flow, external equity, and the 1990s R\&D boom. The Journal of Finance 64(1), 151-185.

Cai, H. and Q. Liu (2009, 04). Competition and Corporate Tax Avoidance: Evidence from Chinese Industrial Firms. Economic Journal 119(537), 764-795.

Carpenter, R. E., S. M. Fazzari, and B. C. Petersen (1998). Financing constraints and inventory investment: a comparative study with high-frequency panel data. Review of Economics and Statistics 80(4), 513-519.

Caves, D. W., L. R. Christensen, and W. E. Diewert (1982). Multilateral comparisons of output, input, and productivity using superlative index numbers. The Economic Journal 92(365), 73-86.

Chen, M. and A. Guariglia (2013). Internal financial constraints and firm productivity in China: do liquidity and export behavior make a difference? Journal of Comparative Economics 41(4), 1123-1140.

Chen, S., Z. Sun, S. Tang, and D. Wu (2011). Government intervention and investment efficiency: evidence from China. Journal of Corporate Finance 17(2), 259-271.

Cimoli, M., G. Dosi, and J. E. Stiglitz (Eds.) (2009). Industrial Policy and Development: the Political Economy of Capabilities Accumulation. Oxford: Oxford University Press.

Coad, A. (2007). Testing the principle of growth of the fitter: the relationship between profits and firm growth. Structural Change and Economic Dynamics 18, 370-386.

Cooper, R., J. Haltiwanger, and L. Power (1999). Machine replacement and the business cycle: lumps and bumps. American Economic Review 89(4), 921-946.

Cull, R. and L. C. Xu (2003). Who gets credit? The behavior of bureaucrats and state banks in allocating credit to Chinese state-owned enterprises. Journal of Development Economics 71(2), 533-559. 
Dollar, D. and S.-J. Wei (2007). Das (wasted) kapital: firm ownership and investment efficiency in China. NBER Working paper No. 13103.

Doms, M. and T. Dunne (1998). Capital adjustment patterns in manufacturing plants. Review of Economic Dynamics 1, 409-29.

Dosi, G. (2007). Statistical regularities in the evolution of industries. a guide through some evidence and challenges for the theory. In F. Malerba and S. Brusoni (Eds.), Perspectives on Innovation. Cambridge, UK: Cambridge University Press.

Dosi, G. and M. Grazzi (2006). Technologies as problem-solving procedures and technologies as input-output relations: some perspectives on the theory of production. Industrial and Corporate Change 15(1), 173-202.

Dosi, G., D. Moschella, E. Pugliese, and F. Tamagni (2015). Productivity, market selection and corporate growth: comparative evidence across US and Europe. Small Business Economics 45(3), 643-672.

Fagiolo, G. and A. Luzzi (2006). Do liquidity constraints matter in explaining firm size and growth? Some evidence from the Italian manufacturing industry. Industrial and Corporate Change 15(1), 1-39.

Fazzari, S., R. G. Hubbard, and B. C. Petersen (1988). Financing constraints and corporate investment. NBER Working Paper No. $238 \%$.

Foster, L., J. Haltiwanger, and C. Syverson (2008). Reallocation, firm turnover, and efficiency: selection on productivity or profitability? American Economic Review 98(1), 394-425.

Freeman, C. (1987). Technology policy and economic policy: Lessons from Japan. Frances Pinter, London.

Freeman, C. and L. Soete (1997). The Economics of Industrial Innovation. Routledge.

Fu, X. and Y. Gong (2011, July). Indigenous and Foreign Innovation Efforts and Drivers of Technological Upgrading: Evidence from China. World Development 39(7), 1213-1225.

Gerschenkron, A. (1962). Economic backwardness in historical perspective: a book of essays. Belknap Press of Harvard University Press Cambridge, MA.

Grazzi, M., N. Jacoby, and T. Treibich (2016). Dynamics of investment and firm performance: comparative evidence from manufacturing industries. Empirical Economics 51(1), 125-179.

Guariglia, A., X. Liu, and L. Song (2011, September). Internal finance and growth: Microeconometric evidence on Chinese firms. Journal of Development Economics 96(1), 79-94. 
Hirschman, A. O. (1958). The strategy of economic development. New Haven/ London: Yale University Press.

Hu, A. G. Z., G. H. Jefferson, and Q. Jinchang (2005, November). R\&D and Technology Transfer: Firm-Level Evidence from Chinese Industry. The Review of Economics and Statistics 87(4), 780-786.

Huggett, M. and S. Ospina (2001). Does productivity growth fall after the adoption of new technology? Journal of Monetary Economics 48(1), 173-195.

Jefferson, G., A. Hu, X. Guan, and X. Yu (2003). Ownership, performance, and innovation in China's large and medium- size industrial enterprise sector. China Economic Review, Elsevier 14(1), 89-113.

Kaldor, N. (1972). The irrelevance of equilibrium economics. The Economic Journal 82(328), 1237-1255.

Landes, D. S. (1969). The unbound Prometheus: technological change and industrial development in Western Europe from 1750 to the present. Cambridge: Cambridge University Press.

Lee, H.-T. (2016). Causes of the changing performance of firms with diverse types of ownerships in China. Seoul Journal of Economics 29, 95-112.

Lee, K. (2013). How can Korea be a role model for catch-up development? a 'capability-based'view. In A. K. Fosu (Ed.), Achieving Development Success: Strategies and Lessons from the Developing World, pp. 25. Oxford University Press Oxford.

Lee, K. and B.-Y. Kim (2009). Both institutions and policies matter but differently for different income groups of countries: determinants of long-run economic growth revisited. World Development 37(3), $533-549$.

Licandro, O., R. Maroto, and L. A. Puch (2003). Innovation, investment and productivity: Evidence from Spanish firms. Documento de Trabajo 30.

Myrdal, G. (1957). Economic Theories and Underdeveloped Regions. London: Duckworth.

Nelson, R. R. and S. G. Winter (1982). An Evolutionary Theory of Economic Change. Cambridge, MA: The Belknap Press of Harvard University Press.

Nilsen, O. A., A. Raknerud, M. Rybalka, and T. Skjerpen (2009). Lumpy investments, factor adjustments, and labour productivity. Oxford Economic Papers 61(1), 104-127.

Nurkse, R. (1953). Problems of capital formation in underdeveloped countries. New York: Oxford University Press. 
Oliveira, B. and A. Fortunato (2006). Firm growth and liquidity constraints: a dynamic analysis. Small Business Economics 27(2-3), 139-156.

Pavitt, K. (1984). Sectoral pattern of technical change: Towards a taxonomy and a theory. Research Policy 13, 343-373.

Polanyi, K. (1944). The great transformation: The political and economic origins of our time. Beacon Press.

Power, L. (1998). The missing link: technology, investment, and productivity. Review of Economics and Statistics $80(2), 300-313$.

Prebisch, R. (1949). The economic development of Latin America and its principal problems. New York: United Nationas, ECLA.

Rosenstein-Rodan, P. N. (1943). Problems of industrialisation of Eastern and South-eastern Europe. The economic journal 53(210/211), 202-211.

Rosenstein-Rodan, P. N. (1961). Notes on the theory of the 'big push'. Springer.

Sakellaris, P. (2004). Patterns of plant adjustment. Journal of Monetary Economics 51 (2), 425-450.

Schiantarelli, F. (1996). Financial constraints and investment: Methodological issues and international evidence. Oxford Review of Economic Policy 12(2), 70-89.

Shima, K. et al. (2010). Lumpy capital adjustment and technical efficiency. Economics Bulletin 30(4), $2817-2824$.

Solow, R. M. (1957). Technical change and the aggregate production function. The Review of Economics and Statistics 39(3), 312-320.

Syverson, C. (2011, June). What determines productivity? Journal of Economic Literature 49(2), 326-65.

Whited, T. M. (2006). External finance constraints and the intertemporal pattern of intermittent investment. Journal of Financial Economics 81(3), 467-502.

Yu, X., G. Dosi, J. Lei, and A. Nuvolari (2015). Institutional change and productivity growth in China's manufacturing: the microeconomics of knowledge accumulation and "creative restructuring". Industrial and Corporate Change 24(3), 565-602.

Zhu, X. (2012). Understanding China's growth: Past, present, and future. Journal of Economic Perspectives 26(4), 103-124. 


\section{Appendix A. Table}

\begin{tabular}{|c|c|c|c|c|c|c|c|c|c|c|}
\hline \multirow[b]{2}{*}{ Year } & \multicolumn{2}{|c|}{ Original Dataset } & \multicolumn{8}{|c|}{ Firms with missing, zero, or negative values, manufacturing firms only } \\
\hline & Total & $\begin{array}{c}\text { Manuf. } \\
\text { (CIC 13-42) }\end{array}$ & Output & $\begin{array}{l}\text { Value } \\
\text { Added }\end{array}$ & Sales & $\begin{array}{l}\text { Original Value of } \\
\text { Fixed Assets }\end{array}$ & $\begin{array}{c}\text { Unemployment } \\
\text { insurance }\end{array}$ & Wage & Welfare & $\begin{array}{c}\text { Employment } \\
(<8)\end{array}$ \\
\hline 1998 & 165097 & 148661 & 543 & 12239 & 5406 & 4555 & 102 & 5 & 180 & 4237 \\
\hline 1999 & 162010 & 146075 & 6111 & 10931 & 6115 & 4881 & 134 & 10 & 167 & 5390 \\
\hline 2000 & 162879 & 147246 & 5533 & 9342 & 5732 & 4615 & 94 & 10 & 118 & 4708 \\
\hline 2001 & 171187 & 155659 & 4216 & 7019 & 4492 & 3412 & 61 & 9 & 76 & 3468 \\
\hline 2002 & 181494 & 165793 & 4014 & 7877 & 4120 & 3163 & 53 & 2 & 49 & 3194 \\
\hline 2003 & 196154 & 181001 & 2672 & 5383 & 2654 & 2473 & 4 & 0 & 20 & 2126 \\
\hline 2004 & 279012 & 258869 & 5789 & 20661 & 5186 & 4097 & 1 & 0 & 2 & 5923 \\
\hline 2005 & 271747 & 250952 & 1965 & 6212 & 1721 & 1501 & 25 & 1 & 41 & 1884 \\
\hline 2006 & 301873 & 278644 & 2044 & 5625 & 2138 & 2021 & 39 & 1 & 35 & 2637 \\
\hline 2007 & 336678 & 312284 & 1144 & 4928 & 1520 & 1768 & 28 & 0 & 115 & 1790 \\
\hline
\end{tabular}

Table A.1: Number of observations of the original dataset, number of observations with missing, zero or negative values for each variable, manufacturing firms only (CIC 13-42). Note: number of observations with missing and negative values for unemployment insurance, wage and welfare. Output and value added in year 2004 are not available. We proxy output as the sum of sales and the difference of inventories between year-end and year-beginning.

\begin{tabular}{|c|c|c|c|c|c|c|c|c|c|c|c|}
\hline Year & $\begin{array}{c}\text { Number of } \\
\text { Firms }\end{array}$ & Output & Employee & $\begin{array}{l}\text { Value- } \\
\text { added }\end{array}$ & Sales & Capital & $\begin{array}{l}\text { Cost of } \\
\text { Labour }\end{array}$ & $\begin{array}{c}\text { Labour } \\
\text { Productiv- } \\
\text { ity }\end{array}$ & Profitability & $\begin{array}{c}\text { L.P. } \\
\text { Growth }\end{array}$ & $\begin{array}{c}\text { Sales } \\
\text { Growth }\end{array}$ \\
\hline 1998 & 108223 & 47702 & 379 & 12779 & 43856 & 34498 & 3448 & 43.7 & 0.158 & & \\
\hline 1999 & 125877 & 48419 & 348 & 13139 & 45273 & 35837 & 3358 & 47.7 & 0.146 & 0.070 & 0.016 \\
\hline 2000 & 125901 & 56572 & 338 & 15126 & 53907 & 37857 & 3702 & 53.6 & 0.138 & 0.060 & 0.049 \\
\hline 2001 & 138284 & 58485 & 307 & 15685 & 55608 & 37917 & 3493 & 59.0 & 0.149 & 0.046 & 0.007 \\
\hline 2002 & 149061 & 63607 & 292 & 17378 & 60680 & 38058 & 3596 & 67.6 & 0.168 & 0.082 & 0.071 \\
\hline 2003 & 162021 & 75851 & 285 & 20396 & 73911 & 38967 & 3849 & 76.2 & 0.176 & 0.099 & 0.129 \\
\hline 2004 & 211384 & 76243 & 236 & 22132 & 73185 & 32746 & 3539 & 87.8 & 0.186 & 0.046 & 0.118 \\
\hline 2005 & 238034 & 89306 & 242 & 23825 & 87461 & 36577 & 4181 & 96.5 & 0.189 & 0.154 & 0.189 \\
\hline 2006 & 265680 & 100683 & 233 & 26838 & 98991 & 38317 & 4614 & 113.6 & 0.195 & 0.170 & 0.178 \\
\hline 2007 & 248193 & 130392 & 245 & 34565 & 128225 & 44916 & 5880 & 136.9 & 0.203 & 0.176 & 0.199 \\
\hline
\end{tabular}

Table A.2: Summary statistics (mean) of dataset used in the paper. Source: our elaboration on CMM. Note: output, value-added, sales, capital and cost of labour are reported at current price, unit: thousands Yuan. Labor productivity is reported at 1998 constant price, unit: thousands Yuan per employee. Capital denotes the original value of fixed capital. The value-added of year 2004 is not directly available from the original dataset, thus, we proxy it using "sales - year beginning inventory + year end inventory + value added tax". 
Table A.3: Aggregation of the 23 registration categories. The (residual) seventh category is not analyzed separately. Source: Jefferson et al. (2003), Annex I.

\begin{tabular}{|c|c|c|c|c|}
\hline Code & Ownership category & & Code & Registration status \\
\hline \multirow[t]{3}{*}{1} & State-owned & & 110 & State-owned enterprises \\
\hline & & & 141 & State-owned jointly operated enterprises \\
\hline & & & 151 & Wholly State-owned companies \\
\hline \multirow[t]{3}{*}{2} & Collective-owned & & 120 & Collective-owned enterprises \\
\hline & & & 130 & Shareholding cooperatives \\
\hline & & & 142 & Collective jointly operated enterprises \\
\hline \multirow[t]{4}{*}{3} & Hong Kong, Macao, Taiwan-invested & & 210 & Overseas joint ventures \\
\hline & & & 220 & Overseas cooperatives \\
\hline & & & 230 & Overseas wholly-owned enterprises \\
\hline & & & 240 & Overseas shareholding limited companies \\
\hline \multirow[t]{4}{*}{4} & Foreign-invested & & 310 & Foreign joint ventures \\
\hline & & Joint ventures & 320 & Foreign cooperatives \\
\hline & & & 340 & Foreign shareholding limited companies \\
\hline & & Foreign MNCs & 330 & Foreign wholly-owned enterprises \\
\hline \multirow[t]{2}{*}{5} & Shareholding & & 159 & Other limited liability companies \\
\hline & & & 160 & Shareholding limited companies \\
\hline \multirow[t]{4}{*}{6} & Private & & 171 & Private wholly-owned enterprises \\
\hline & & & 172 & Private cooperatives enterprises \\
\hline & & & 173 & Private limited liability companies \\
\hline & & & 174 & Private shareholding companies \\
\hline \multirow[t]{3}{*}{7} & Other domestic & & 143 & State-collective jointly operated enterprises \\
\hline & & & 149 & Other jointly operated enterprises \\
\hline & & & 190 & Other enterprises \\
\hline
\end{tabular}

\section{Appendix B. Relative TFP and firm growth}

The total factor productivity (TFP) is calculated using a non-parametric method, the Tornqvist index number, as adopted by Solow (1957); Caves et al. (1982); Brandt et al. (2012). This approach can be interpreted as an exact productivity measure without estimating parameters (Caves et al., 1982). The intuition is that cost-minimizing firm will equalize the relative factor price to the local elasticity of substitution that the production technology allows. As a result, factor shares can be used to control for input substitutability.

To compare the productivity level across firms within the same sector (within 3-digit sectors in this paper), Caves et al. (1982) propose the multilateral productivity measure:

$$
\ln (T F P)_{i, t}=\left(q_{i, t}-\bar{q}_{t}\right)-\widetilde{s_{i, t}}\left(l_{i, t}-\bar{l}_{t}\right)-\left(1-\widetilde{s_{i, t}}\right)\left(k_{i, t}-\bar{k}_{t}\right)
$$

where $q_{i, t}, l_{i, t}$ and $k_{i, t}$ are the log of (real) value added, labour, and capital of firm $i$ in year 

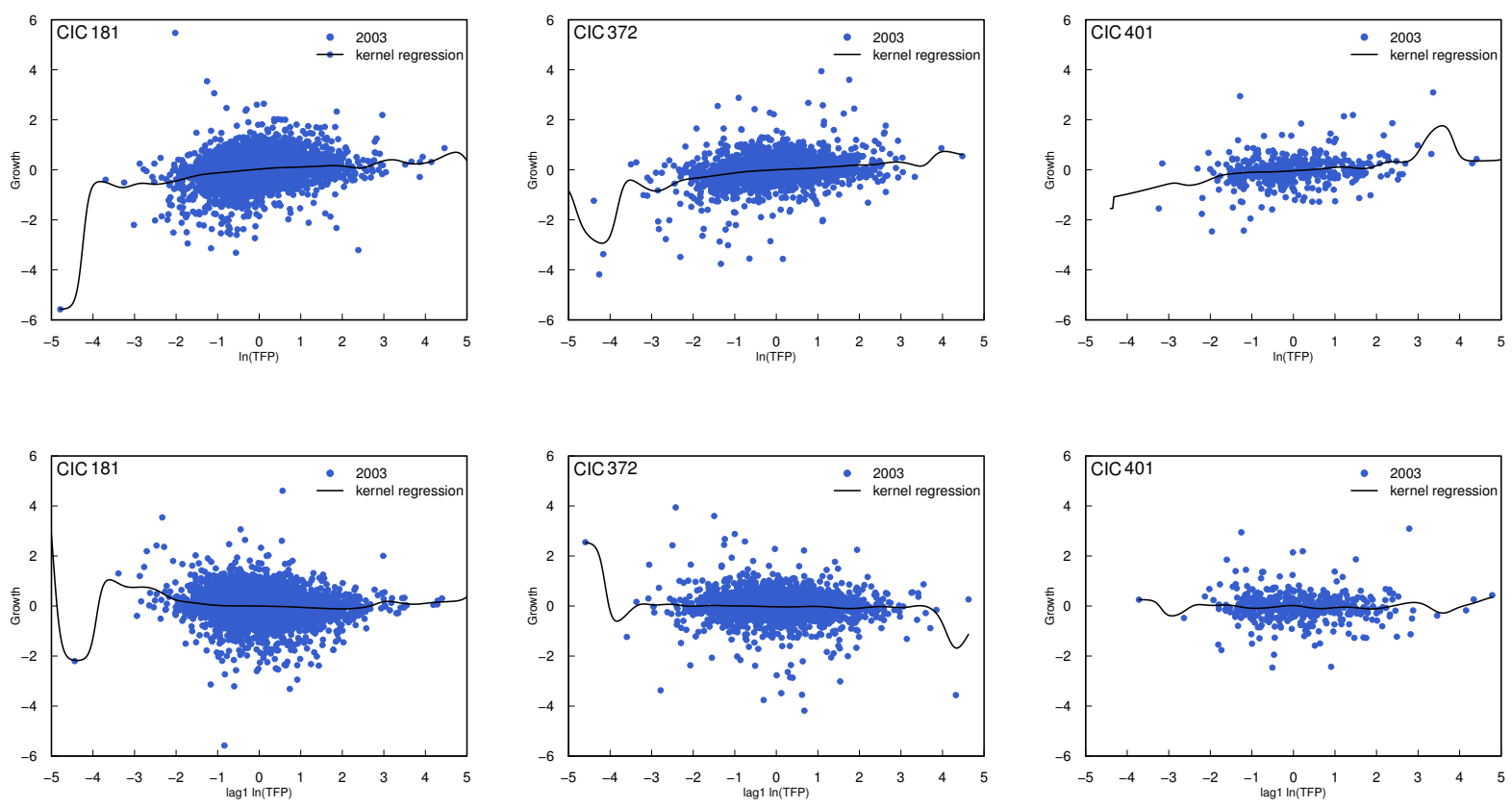

Figure B.1: Total factor productivity - Growth relationship in selected 3-digit sectors (textile clothing, automobiles and communication equipment) - kernel regression of 2003. Note: the first row shows current relationship and the second row shows lagged relationship. Source: our elaboration on CMM.

$t ; \bar{q}_{t}, \bar{l}_{t}$ and $\bar{k}_{t}$ are the sectoral averages in year $t ; \widetilde{s_{i, t}}=\left(s_{i, t}+\bar{s}_{t}\right) / 2$ is the weight on the labour input. $s_{i, t}$ is the share of wage bill in value added of firm $i$ in year $t$ and $\bar{s}_{t}$ is the average wage share of all firms in the same sector in year $t$. It represents a comparison with the hypothetical average firm in the industry. This measure does allow for a comparison with the same benchmark while maintaining technology heterogeneity, i.e., the input weights differ across observations.

The non-parametric relationship between sales growth and current or lagged one TFP is shown in Figure B.1, revealing a positive but mile relationship between contemporaneous TFP and relative growth rates.

The distributions of the parameter estimates of the fixed effects model across 1613 -digit sectors reveals regularities similar to those using labour productivity measure (shown in Figure B.2), that the coefficients of current and lagged TFP are similar in absolute magnitudes, but have opposite signs. The explanatory power of TFP variables to sales growth is around $18 \%$, and the majority of the explanatory power of TFP is ca[tired by TFP changes, as shown in Figure B.3. 


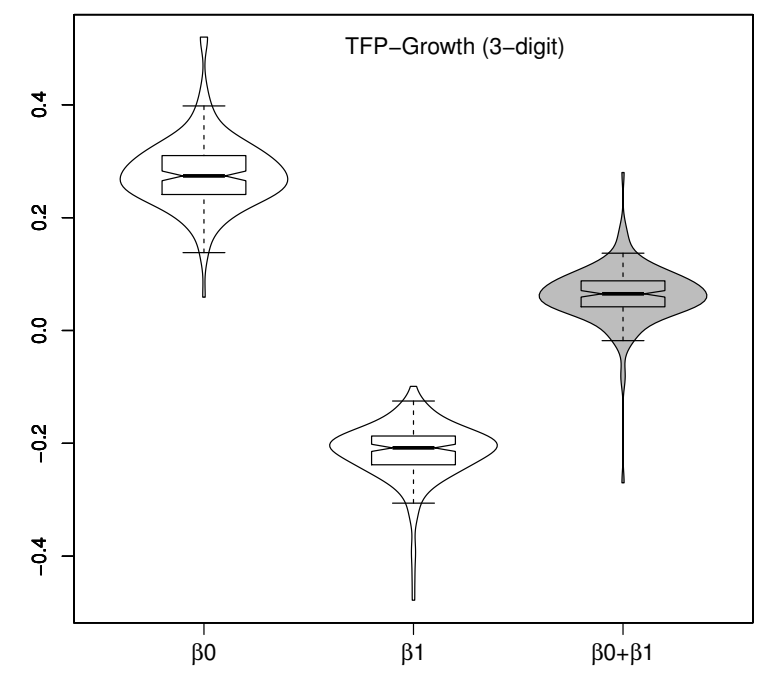

Figure B.2: Total factor productivity - Growth relationship at 3-digit and 4-digit sectoral level respectively. Distribution of parameters $\beta_{0}, \beta_{1}$ and $\beta_{0}+\beta_{1}$ of the baseline model.

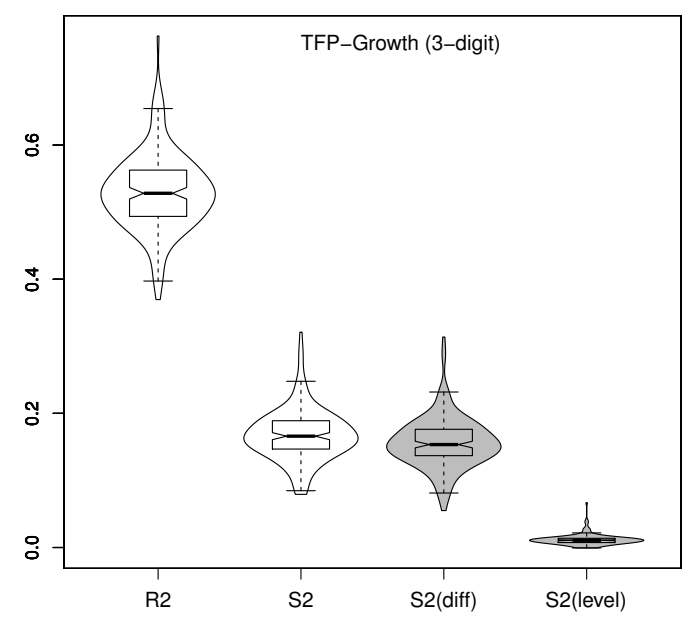

Figure B.3: Total factor productivity - Growth relationship. Distribution of $R^{2}$ and $S^{2}$. 


\section{Appendix C. Relative productivities and relative profitabilities}

The non-parametric kernel regression between profitability and current or lagged one productivities reveal a robust positive relationship (see in Figure C.4).
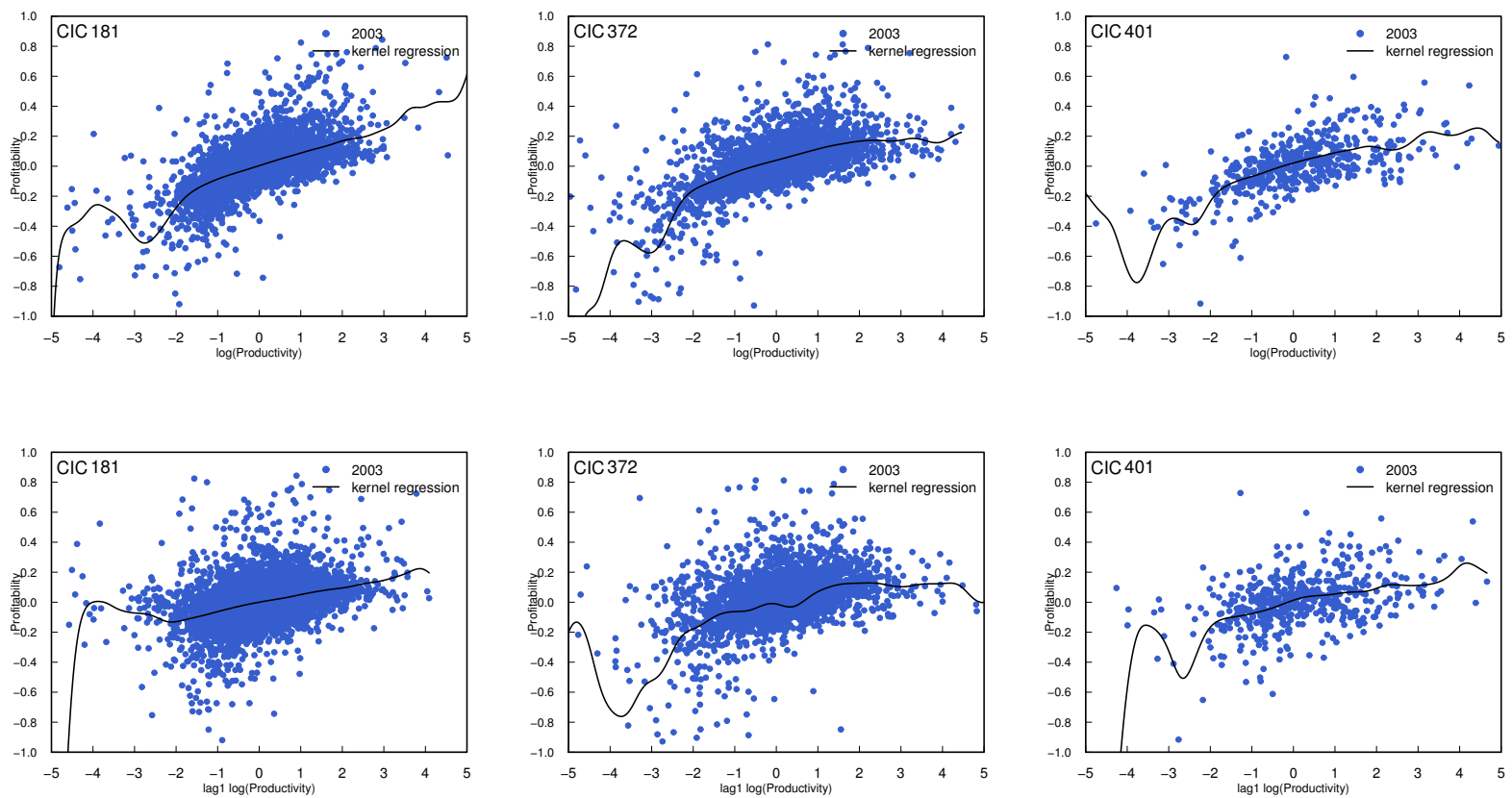

Figure C.4: Productivity - Profitability (gross profit margins) relationship in selected 3-digit sectors (textile clothing, automobiles and communication equipment) - kernel regression of 2003. Note: the first row shows current relationship and the second row shows lagged relationship. Source: our elaboration on CMM.

Adopting similar estimation methodologies as in Section 4, we estimate the effects of contemporaneous and one-lag productivities on profitability for each 3-digit sector, using fixed-effects model. The distributions of fixed-effects coefficients are shown in Figure C.5. Firms contemporaneous productivity shows a significant and positive effect on relative profitabilities.

The explanatory power of productivity-related variables to profitabilities is over $20 \%$ (see Figure C.6) and it is mostly due to productivity levels rather than variations. Notice that, the distributions of $S^{2}, S_{\Delta}^{2}$ and $S_{a}^{2}$ show some bi-modality, i.e., the probability density is highest at around $10 \%$ and $30 \%$ in the distribution of $S^{2}$. This property of bi-modality can be interpreted by the large variations of the explanatory powers of productivities between State-owned enterprises and other ownership types (as shown in Figure C.7). The $S^{2}$ s of State-owned enterprises are distributed over a wide support, the median of the distribution is $25 \%$ and that is significantly lower than the $S^{2}$ of 


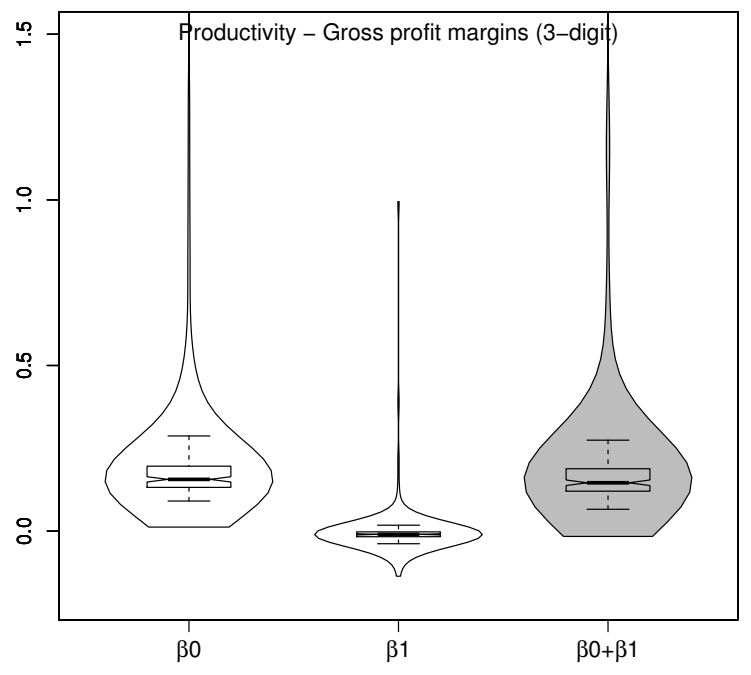

Figure C.5: Productivity - Profitability (gross profit margins) relationship at 3-digit sectoral level. Distribution of parameters $\beta_{0}, \beta_{1}$ and $\beta_{0}+\beta_{1}$ of the baseline model.

the other ownership types (around 40\%). Conversely, the $S^{2}$ of foreign-invested and HMT-invested are the largest.

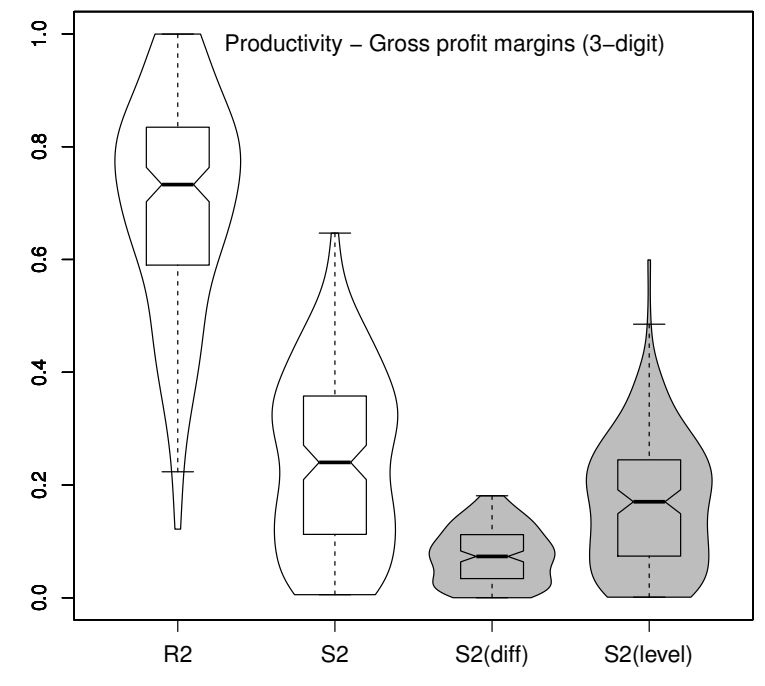

Figure C.6: Productivity - Profitability (gross profit margins) relationship at 3-digit sectoral level. Distributions of $R^{2}, S^{2}, S_{\Delta}^{2}$ and $S_{a}^{2}$. The shaded violins refer to $S_{\Delta}^{2}$ and $S_{a}^{2}$. 

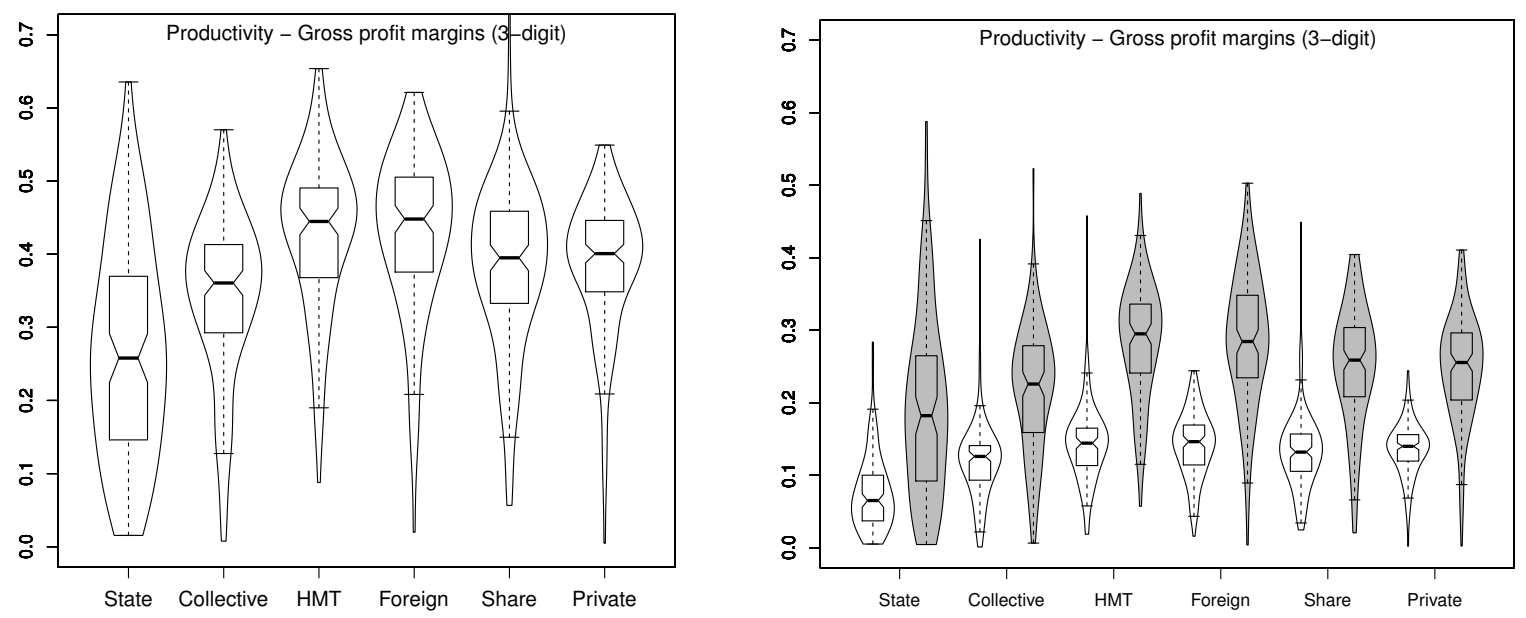

Figure C.7: Productivity - Profitability (gross profit margins) relationship. Distributions (left) of $S^{2}$ and decomposition (right) of $S^{2}\left(S_{\Delta \pi_{i, t}}^{2}\right.$ and $\left.S_{\bar{\pi}_{i, t}}^{2}\right)$ by ownership types. The shaded violins refer to $S_{a}^{2}$ and the un-shaded violins refer to $S_{\Delta \pi_{i, t}}^{2}$. 


\section{Appendix D. Investment spikes definition}

In the literature, there are four methods of identifying investment spikes, (i) absolute method: investment rate greater than $20 \%$ (the volatility of these ratio decreases with the capital stock, spikes are much common for small than for large firms); (ii) relative method; (iii) linear method and (iv) kernel method, which are summarized and compared by Grazzi et al. (forthcoming). In this paper, we adopt kernel method to identify the investment spikes:

$$
S_{i, t}= \begin{cases}1 & \text { if } I_{t} / K_{i, t-1}>\alpha E\left[\left(I_{i, t} / K_{i, t-1}\right) \mid K_{i, t-1}\right] \\ 0 & \text { otherwise }\end{cases}
$$

where $\alpha$ is set to 1.75 and the conditional expected value is obtained through kernel estimation within each 2-digit sector. For example, the threshold calculated by kernel regression for the overall sample is shown in Figure D.8. Investment rates above the threshold are defined as investment spikes. $^{29}$
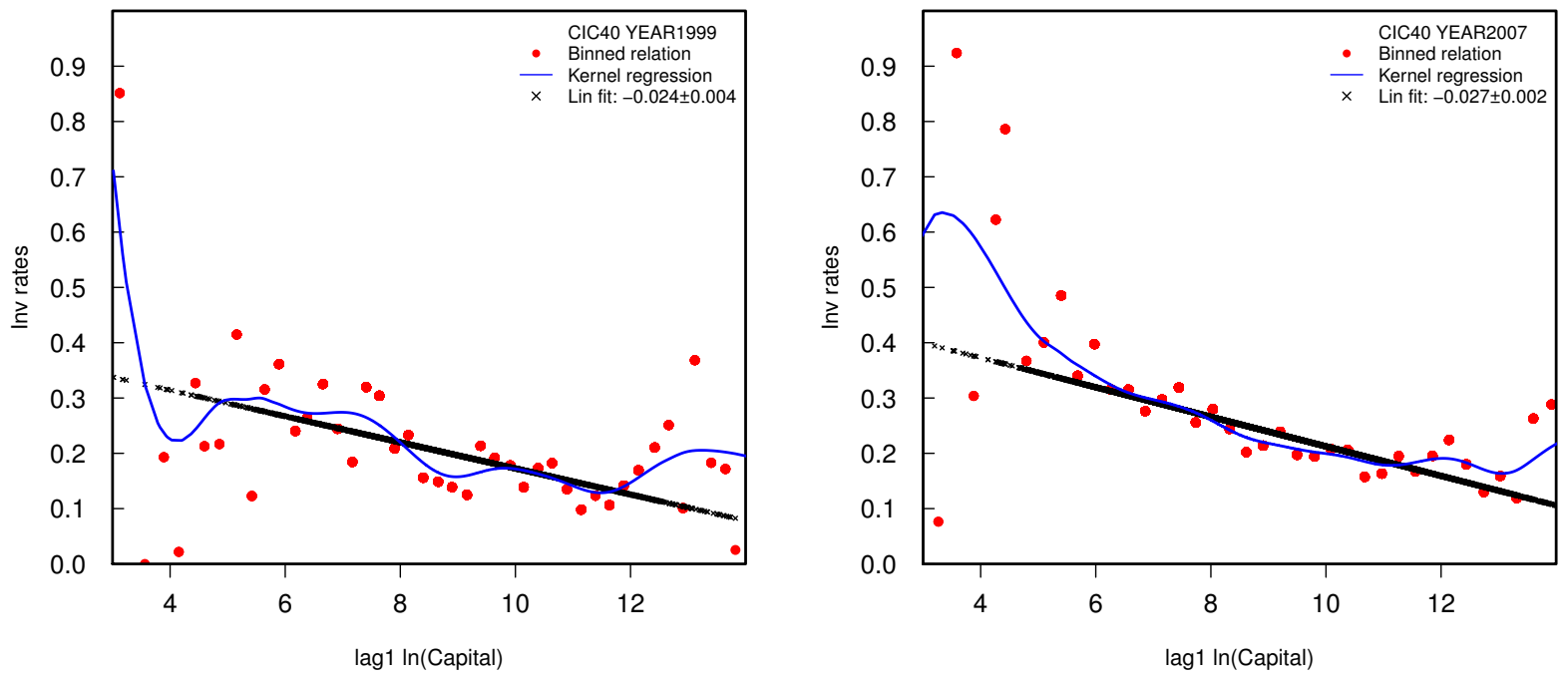

Figure D.8: Kernel regression (curve), binned relation (50 equal spaced bin; dots) and OLS regression (cross mark) of investment rates on (lag1) $\ln ($ capital), communication equipment computers manufacturing sector, in 1999 and 2007. Source: our elaboration on CMM.

\footnotetext{
${ }^{29}$ In the data, $3 \%$ of firms have investment rate greater than 3 . Thus, we delete firms with investment rate greater than 3 for at least one year.
} 